\title{
38. LATEST CRETACEOUS AND EOCENE PALEOENVIRONMENTS IN THE BLAKE-BAHAMA BASIN, WESTERN NORTH ATLANTIC ${ }^{1}$
}

\author{
A. H. F. Robertson, Department of Geology, University of Edinburgh, Edinburgh EH9 3JW, Scotland
}

\begin{abstract}
At Site 534 in the Blake-Bahama Basin, western North Atlantic, an interval of $68 \mathrm{~m}$ of Maestrichtian (Upper Cretaceous) and upper middle to upper Eocene sediments consists of terrigenous siltstones, mudstones, and varicolored zeolitic claystones; minor recovery of micritic limestones, porcellanites, and quartzitic chert was made at this site as well. Comparisons with other Deep Sea Drilling Project (DSDP) sites in the western North Atlantic suggest that the following formations are present in this interval: Hatteras (Maestrichtian), Plantagenet (Maestrichtian and upper Eocene), Bermuda Rise (upper middle to upper Eocene), and the basal Blake Ridge Formation (upper middle to upper Eocene). Recognition of a Tertiary interval of the Plantagenet allows that formation to be divided into lower and upper informal units. Condensation makes this formal lithostratigraphic subdivision difficult.

Together the formations record marked net condensed sedimentation (average rate ca. $2.5 \mathrm{~m} / \mathrm{m}$.y.) in strongly oxidizing bottom waters. From sedimentary structures and petrography, it is inferred that the terrigenous siltstones and micritic limestones were redeposited from the continental margin by turbidity currents. Chemical data plus petrography confirm relatively high plankton productivity during the upper Eocene. Much of the nonrecovered Eocene interval may represent chert and porcellanite. Fragments recovered were formed by replacement of relatively porous calciturbidites by opal-CT and quartz. Radiolarians in interbedded claystones rich in clinoptilolite show extensive dissolution. Relative to typical hemipelagic sediments, the claystones are enriched in many metals $(\mathrm{Cu}, \mathrm{Ni}, \mathrm{Zn}, \mathrm{Pb})$, particularly within manganese micronodules. The metal accumulation is related to a $30-\mathrm{m} . \mathrm{y}$. period of slow net sediment accumulation, rather than to hydrothermal enrichment or to upward mobilization of metals from the underlying reduced Hatteras black shale facies.

Elsewhere in the Blake-Bahama Basin, at Site 391, $22 \mathrm{~km}$ to the northwest, upper Eocene facies are missing, reportedly due to deep seafloor erosion of up to $800 \mathrm{~m}$ of the sedimentary succession. By contrast, the discovery that this interval is preserved at nearby Site 534 points to much less extensive seafloor erosion, possibly mostly in the Oligocene, which is missing at both DSDP Sites.
\end{abstract}

\section{INTRODUCTION}

DSDP Leg 76 in the Blake-Bahama Basin (western Central Atlantic) penetrated circa $68 \mathrm{~m}$ of hemipelagic siltstones, mudstones, zeolitic claystones, claystones, metalliferous mudstones, minor carbonates, and chert horizons deposited during the latest Cretaceous or Eocene. This dating was unexpected, because at the adjacent Site 391, $22 \mathrm{~km}$ to the northwest, the Eocene facies are absent. Organic maturation determinations at Site 391 (Dow, 1978) implied that the rocks of the underlying Upper Cretaceous Plantagenet and Hatteras formations had been more deeply buried, followed by seafloor erosion of up to $800 \mathrm{~m}$ of sediment from below the Miocene unconformity. The existence of upper Eocene sediments of the Bermuda Rise Formation at Site 534 appears to contradict the hypothesis of very extensive deep erosion (Sheridan, Gradstein, et al., this volume). Instead, extremely slow condensed deposition took place over 30 m.y. on an oxidizing seafloor with probably only relatively minor erosion, presumably by bottom currents. Conditions were conducive to intense burrowing, formation of manganese micronodules, and metal enrichment. In this chapter the sediments are interpreted in the light of shipboard core descriptions, supplemented by results of X-ray diffraction, X-ray fluorescence, and

\footnotetext{
${ }^{1}$ Sheridan, R. E., Gradstein, F. M., et al., Init. Repts. DSDP, 76: Washington (U.S. Govt. Printing Office).
}

scanning-electron and optical microscopy. Interpretation is, however, hampered by zero or minimal recovery of some cores, particularly Cores 21 through 23 .

\section{STRATIGRAPHY}

The Upper Cretaceous and upper Eocene succession drilled at Site 534 corresponds in certain respects to the Plantagenet Formation, Bermuda Rise Formation, and the Blake Ridge Formation, as defined by Jansa et al. (1979, Fig. 1). In brief, at the type locality, the Plantagenet Formation (Site 386) comprises $92.3 \mathrm{~m}$ of variegated claystones; colors range from dusky yellowish brown, moderate brown, to dusky dark red with some light greenish gray intercalations (Jansa et al., 1979). Zeolites and clay minerals make up the bulk of the sediment, with the addition of iron and manganese oxides, including manganese micronodules. Minor volcanic ash, poorly preserved radiolarians, and agglutinating foraminifers are also present in small quantities. The regional identifying features are the variegated color, clayey and locally zeolitic composition, lack of biogenic carbonate, low accumulation rates, and the presence of seismic Horizon $A^{*}$ in the upper part of the unit. Sites where the Plantagenet Formation has been drilled are shown in Figure 2. Ages recorded range from Maestrichtian to possibly early Paleocene.

The Bermuda Rise Formation is defined as sediment enriched in biogenic silica, porcellanite, and chert. At the type area at Site 387 (Fig. 3), the formation is about 


\begin{tabular}{|c|c|c|c|c|c|c|}
\hline \multicolumn{2}{|c|}{ Formation } & $\begin{array}{c}\text { Cored } \\
\text { interval } \\
\text { (core-section, } \mathrm{cm} \\
\text { from top of section) }\end{array}$ & $\begin{array}{c}\text { Drilled } \\
\text { thickness } \\
\text { (m) }\end{array}$ & $\begin{array}{l}\text { Recovered } \\
\text { thickness } \\
\text { (m) }\end{array}$ & Lithology & Age \\
\hline \multicolumn{2}{|c|}{$\begin{array}{l}\text { Blake Ridge } \\
\text { (below Great } \\
\text { Abaco Member) }\end{array}$} & $\begin{array}{c}19-1,6 \\
\text { to } \\
19-2,79\end{array}$ & 2.3 & 2.20 & $\begin{array}{l}\text { Greenish siltstone, } \\
\text { mudstones, laminated } \\
\text { with graded terrigenous } \\
\text { turbidites }\end{array}$ & $\begin{array}{l}\text { late middle } \\
\text { Eocene to } \\
\text { late Eocene }\end{array}$ \\
\hline \multicolumn{2}{|c|}{ Bermuda Rise } & $19 \cdot 2,80$ & 4.1 & 4.15 & $\begin{array}{l}\text { Grayish green siltstone, } \\
\text { siliceous chalk, yellow, } \\
\text { olive, orange, brown, } \\
\text { varicolored siliceous } \\
\text { claystones and } \\
\text { procellanous claystones }\end{array}$ & $\begin{array}{l}\text { late middle to } \\
\text { late Eocene }\end{array}$ \\
\hline \multirow[t]{2}{*}{ Plantagenet } & $\begin{array}{l}\text { upper } \\
\text { unit }\end{array}$ & $\begin{array}{c}20-2,125 \\
\text { (starts) }\end{array}$ & 35.2 & 1.37 & $\begin{array}{l}\text { Mottled and varicolored } \\
\text { siliceous claystones } \\
\text { (chert and porcellanite } \\
\text { clasts) }\end{array}$ & late Eocene \\
\hline & $\begin{array}{l}\text { lower } \\
\text { unit }\end{array}$ & $\begin{array}{r}? 24-1,1 \\
\text { (starts) }\end{array}$ & 28.2 & 8.60 & $\begin{array}{l}\text { Mottled and varicolored } \\
\text { claystones with Mn-micro. } \\
\text { nodules, but no chert }\end{array}$ & $\begin{array}{l}\text { Maestrichtian } \\
\text { (Late Cretaceous) }\end{array}$ \\
\hline \multicolumn{2}{|c|}{ Hatteras } & $\begin{array}{l}27-1,1 \\
\text { (starts) }\end{array}$ & $\begin{array}{l}\text { Not } \\
\text { specified } \\
\text { here }\end{array}$ & $\begin{array}{l}\text { Not } \\
\text { specified } \\
\text { here }\end{array}$ & $\begin{array}{l}\text { Dark gray to black } \\
\text { laminated silty } \\
\text { claystone }\end{array}$ & $\begin{array}{l}\text { Late } \\
\text { Cretaceous }\end{array}$ \\
\hline
\end{tabular}

Figure 1. Summary of drilling records, age, and lithology of the Plantagenet, Bermuda Rise, and Blake Ridge formations in Hole 534A.

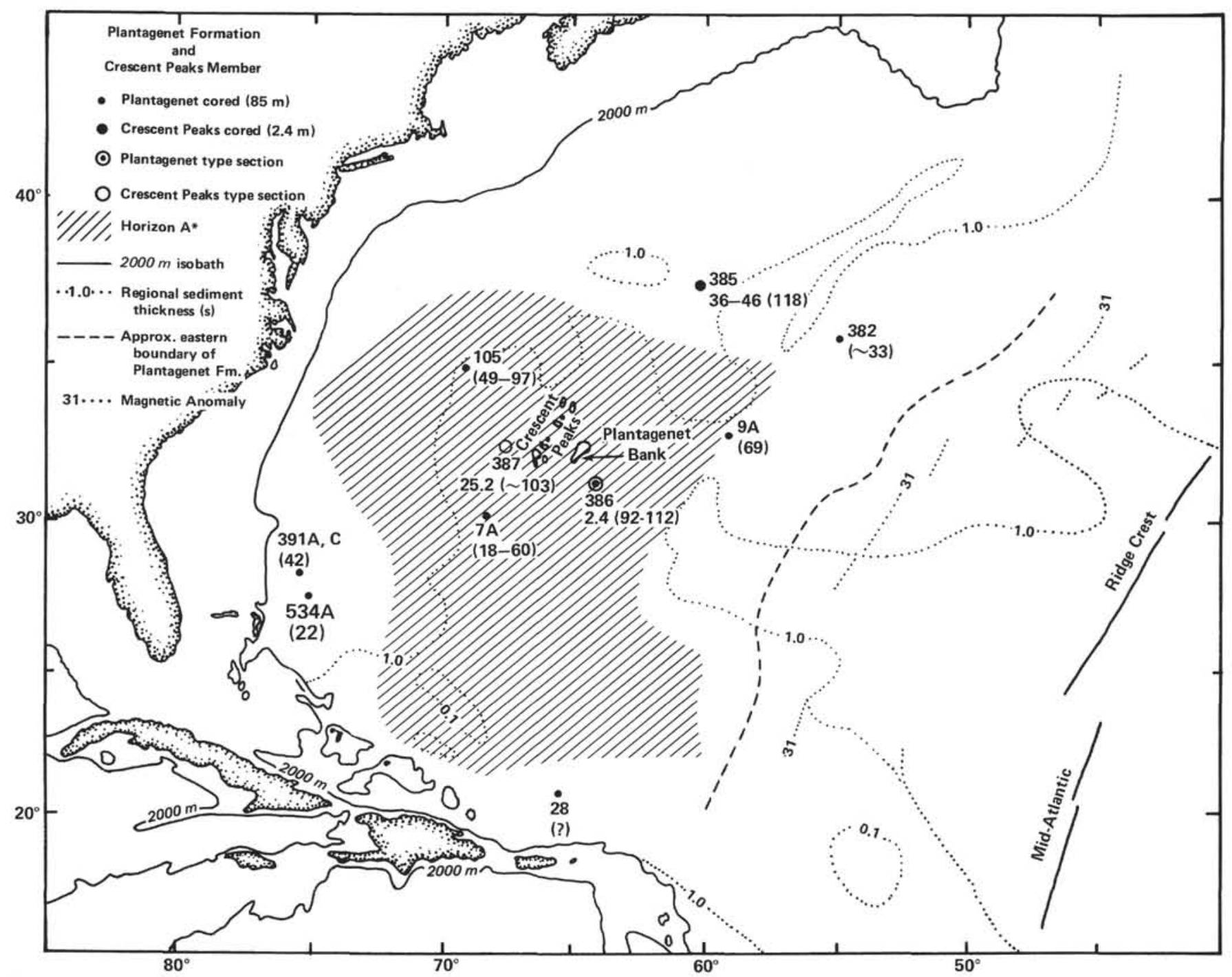

Figure 2. Map of the western Central Atlantic showing DSDP sites where the Upper Cretaceous Plantagenet Formation has been drilled (modified after Jansa et al., 1979). (Thicknesses in meters in parentheses refer to the Plantaganet Formation, those without parentheses, to the Crescent Peaks Member.) 


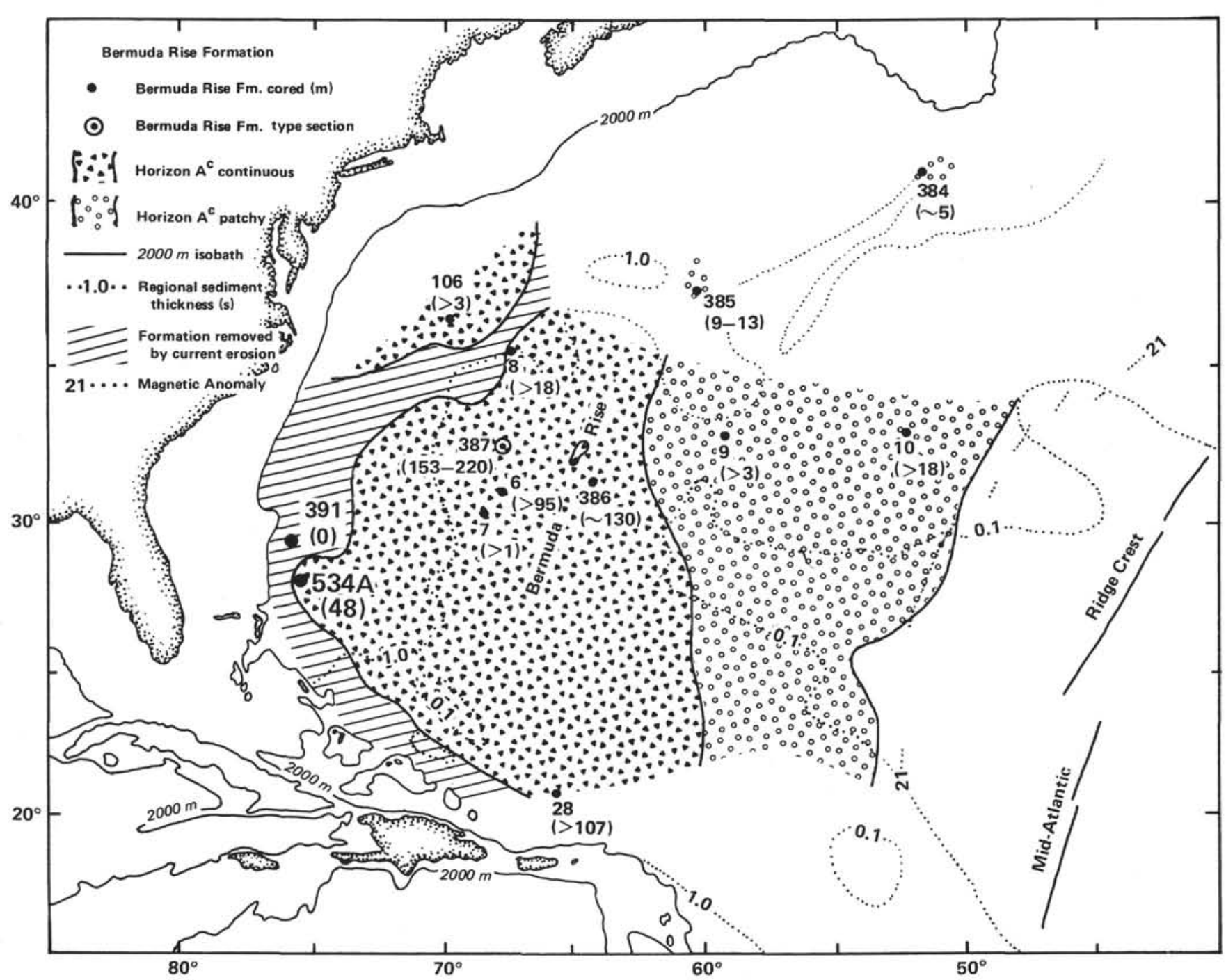

Figure 3. Map of the western Central Atlantic showing DSDP sites where the Eocene Bermuda Rise Formation has been drilled. (Note the absence of recovered Bermuda Rise Formation at Site 391, $22 \mathrm{~km}$ to the northwest of Hole 534A, and in the Cat Gap area. Formation thickness in meters is indicated in parentheses. Modified after Jansa et al., 1979.)

$200 \mathrm{~m}$ thick and consists of chert, silicified claystone, radiolarians, and calcareous mudstone. Notably, the colors are mostly shades of greenish gray to olive gray. The top of the Bermuda Rise Formation, where cherts and porcellanites disappear, corresponds to the widespread seismic Horizon $A^{c}$ at most drill sites away from the continental margin. The ages recorded by nannofossils and planktonic foraminifers range at different sites from latest Paleocene to middle Eocene.

The upper contact of the Bermuda Rise Formation with the overlying Blake Ridge Formation has not been cored previously. At Site 106 there is a change from greyish green to dark greenish gray, across a 50 -m uncored interval, with a marked increase in terrigenous matter, coupled with disappearance of the porcellanites and siliceous clays, which characterize the Bermuda Rise Formation (summary by Jansa et al., 1979). The Blake Ridge Formation is dominated by widespread greenish gray and brown hemipelagic mud and silt, dominantly silicic turbidites, and mass-flow deposits of the Eocene to the Recent. In seaward sites (e.g., 386, 387) the formation overlies the Bermuda Rise siliceous sediments and is thus as old as the middle Eocene. Mixed terrigenous and graded beds deposited in the Eocene at the base of the Blake Ridge Formation entrain large volumes of pelagic material within otherwise terrigenous-derived turbidites. Locally in the Blake-Bahama Basin, the Miocene is dominated by redeposited platform and slope deposits of the Great Abaco Member of the Blake Ridge Formation (Bliefnick, Robertson, and Sheridan, this volume).

Comparisons of the Site 534 sediments with the defined Blake Ridge, Bermuda Rise, and Plantagenet formations indicate the following: First, the $4.2 \mathrm{~m}$ of greenish siliceous siltstones of Core 19 are reminiscent of the basal Blake Ridge Formation, in the predominantly greenish gray color and mixed biogenic and terrigenous origin, without cherts or porcellanites. Secondly, the Bermuda Rise Formation can be taken where porcellanous sediments first appear (Core 19, Section 2 
at $80 \mathrm{~m}$ ). Below this section (in Core 19, Section 3), the terrigenous component decreases; colors become more variable, ranging from grayish green to olive green and yellowish gray. Porcellanous claystones are again present. Sediments in Core 20, Section 1 and Section 2 to $125 \mathrm{~cm}$, are less terrigenous, even more variable in color (e.g., dusky yellow orange, olive, pale brown, pinkish gray, reddish, and, in places, varicolored), but still include porcellanous claystones, consistent with the Bermuda Rise Formation. Thirdly, below Core 20, Section 2 at $125 \mathrm{~cm}$ there is a switch to more homogenous claystones without porcellanous sediments. Chert in the core catcher of Core 22 is regarded as caved (see later discussion). This interval, which extends down to the top of Core 24, conforms to the definition of the Plantagenet Formation; it is characterized by intense color mottling with hues ranging from olive, brownish, yellowish, reddish, purple, orange, to dark gray. The zero to minimal recovery of Cores 21,22 , and 23 could well be explained by highly resistant cherts in this interval; fragments were recovered. If so, this Plantagenet would be anomalous.

In summary, on the basis of lithology, the sediments of Site 534 between the Great Abaco Member (Miocene) and the Hatteras Formation (Upper Cretaceous) can be assigned to the basal part of the Blake Ridge Formation and the Bermuda Rise and Plantagenet formations. Transitions across these formations have been cored for the first time. However, the poor recovery of some intervals, the condensed nature, and lithological variety, lead us to question the value of attempting to apply formal stratigraphic names to this interval of the Atlantic latest Cretaceous and Tertiary.

\section{MICROFOSSIL AGES}

The microfossil age data further demonstrate that the interval now identified as the Plantagenet Formation is in fact composed of two distinct ages: Maestrichtian and upper Eocene. Previously, Plantagenet Formation sediments have been dated as Maestrichtian to earliest Paleocene (summarized by Jansa et al., 1979).

The lower part of the Plantagenet Formation (Core 24) contains agglutinating as well as planktonic foraminifers (e.g., Globotruncana arca), diagnostic of the lower Maestrichtian (M. Moullade, personal communication, 1981). There is no sign of mixing with a younger fauna, as seen on the adjacent continental rise during the early Tertiary. This is surprising, as P. Roth (this volume) records definite Tertiary nannofossils, possibly of the late Eocene, from Core 25, with the addition of only two Late Cretaceous specimens. P. Roth (this volume) points out that the mixed microfossils could either have resulted from sediment reworking or possibly from caving during drilling. In this context, it was noted that the gamma-ray log drops from the Bermuda Rise to the Plantagenet Formation (see Site 534 report), when it would have been expected to rise. This could be due to extensive washout and enlargement of the hole, allowing Eocene material to drop into the Cretaceous inter$\mathrm{val}$. This possibility is increased by the fact that Core 26 is barren of nannofossils, so that contamination in Core 25 could easily have taken place. Thus Core 24 is assigned to the Maestrichtian Plantagenet Formation.
The interval also assigned to the Plantagenet Formation from Cores 20, Section 2, $125 \mathrm{~cm}$ to Core 23, core catcher, by contrast yields planktonic foraminifers tentatively dated as Eocene (M. Moullade, personal communication, 1981). P. Roth (personal communication, 1981) confirms that the nannoplankton are late middle to late Eocene. Unfortunately, there was no recovery in Core 21 and recovery in Cores 22 and 23 was minimal, possibly because resistant chert was not cored. Thus for the first time a distinctive Tertiary Plantagenet interval can be recognized and referred to as an upper Plantagenet unit, distinct from the Maestrichtian and possibly lowest Tertiary lower Plantagenet unit not recognized before. With better recovery it might be possible to erect a separate lithostratigraphical unit for the upper Plantagenet, although as noted above, the value of lithostratigraphic subdivisions in such condensed variable sediments is questionable.

\section{LITHOLOGIES}

In view of the gradational nature of the Blake Ridge, Bermuda Rise, and Plantagenet facies boundaries, the various lithologies are described separately in order of upward occurrence. The chief facies recognized are (1) varicolored claystone, (2) chert and porcellanous claystone, (3) micritic limestone, and (4) siliceous mudstone and siltstone.

\section{Varicolored Silty Claystones}

At the top of the Hatteras Formation, typical black shales and mudstones with quartzitic laminations pass into a zone of alternating variegated claystones (Fig. 4A) and black silty shales (Fig. 4B). Above this, varicolored silty claystones dominate most of the interval assigned earlier to both the lower and upper units of the Plantagenet Formation (Cores 20-26, inclusively, Fig. 1), but then decrease upward through the Bermuda Rise Formation. Color variants are grayish olive, olive gray, light olive brown, grayish red, reddish brown, blackish red, yellowish orange, and dusky yellow. The varied colors exist as banding, irregular mottles, and subspherical patches up to several centimeters across, as shown in Figures $4 \mathrm{~A}$ and $5 \mathrm{~A}$. Some cores show traces of parallel lamination and burrowing (Fig. 4A). The scale of color banding is typically 0.5 to $2 \mathrm{~cm}$, (e.g., Core 24 , Section $3)$. Slightly more silty cross lamination is occasionally seen (e.g., Core 24, Section 3, 73-75 cm). Often, mottling and burrowing destroy original primary lamination (Fig. 5A). Grading, and vague parallel and small-scale convolute lamination are seen (e.g., Core 24 , Section 2 , $43-45 \mathrm{~cm}$ ). Core 20 , Section 3 is highly mottled, burrowed, and shows small reduction spots up to $2 \mathrm{~cm}$ in diameter (Fig. 5A). A notable feature is the presence of numerous black manganese micronodules up to $0.5 \mathrm{~cm}$ in diameter (e.g., Core 24, Section 2). Fine laminations swirl around the micronodules, showing they formed prior to significant compaction (Fig. 6A, B).

Examination of smear-slides on the ship showed that, in terms of grain size, the claystones locally contain up to $20 \%$ sand in graded and laminated intervals up to 7 $\mathrm{cm}$ thick. Silt is up to $40 \%$, whereas clay ranges from 15 to $64 \%$. In some smear slides, zeolite makes up $70 \%$, 


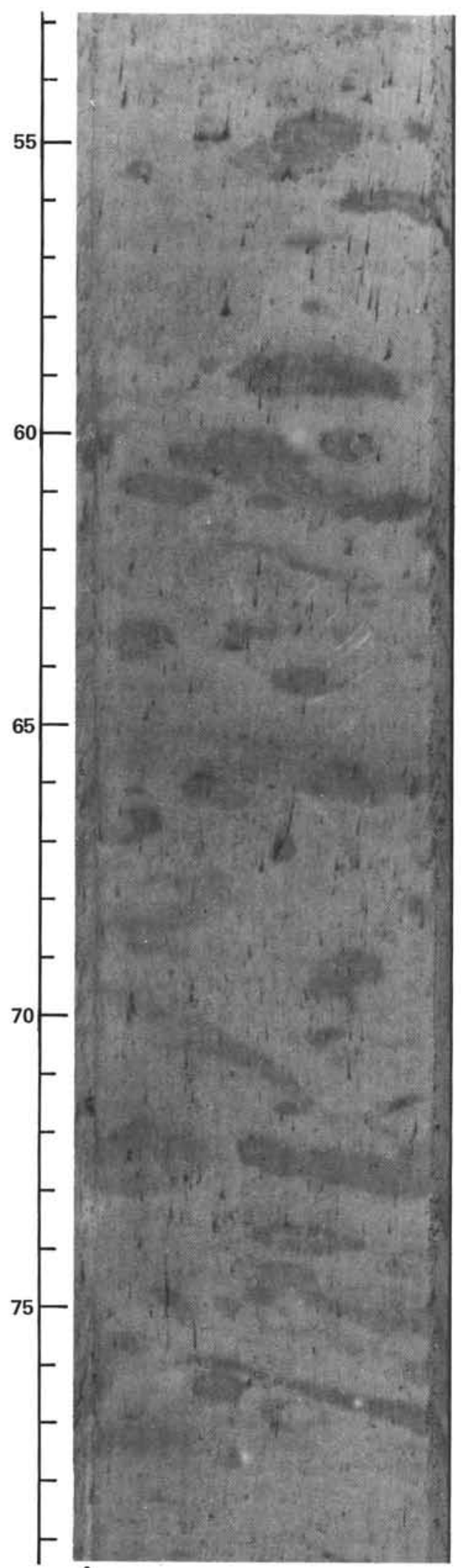

A

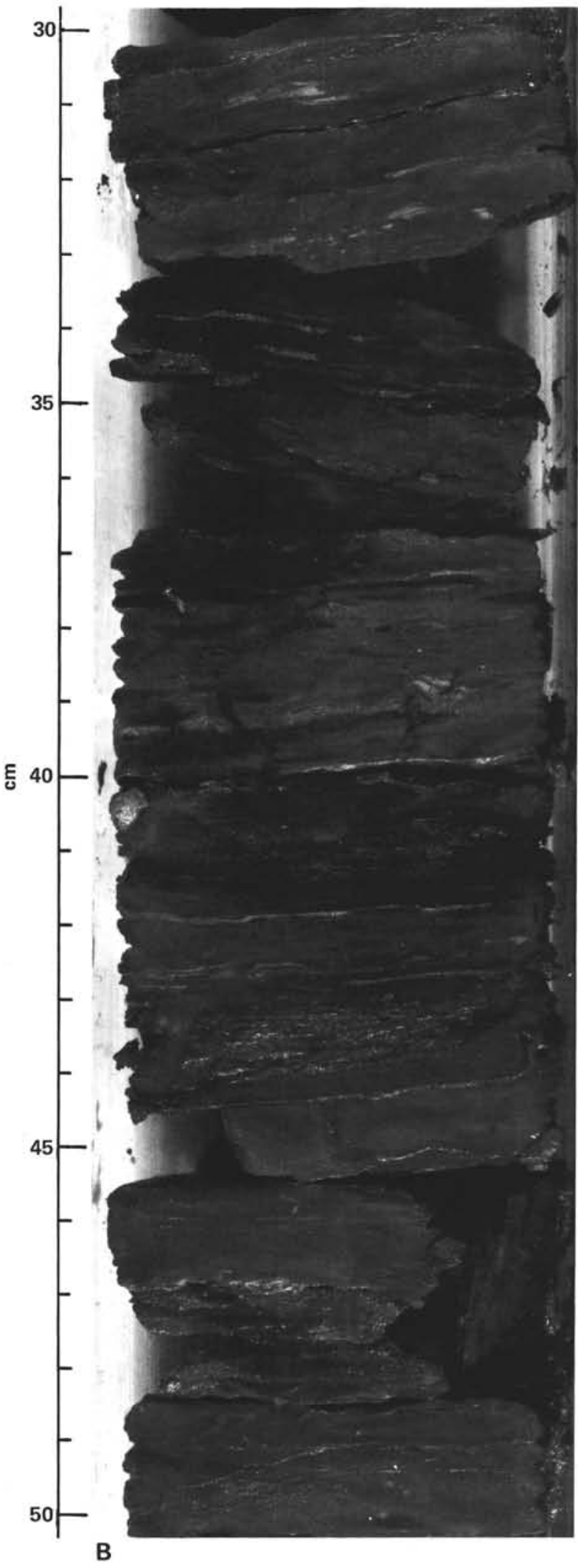

B

Figure 4. Core photographs of the top of the Upper Cretaceous Hatteras Formation transitional upward to the lower unit of the Plantagenet Formation. A. Highly burrowed varicolored zeolitic claystones, just above the black, organic-rich claystones and siltstones characteristic of the Hatteras Formation (Core 27, Section 3, 53-79 cm). B. Highly burrowed, varicolored silty claystones showing intense burrowing, stringers, and tiny lenses of quartzose silt signifying some bottom-current reworking (Core 27, Section 1, 30-50 cm). 

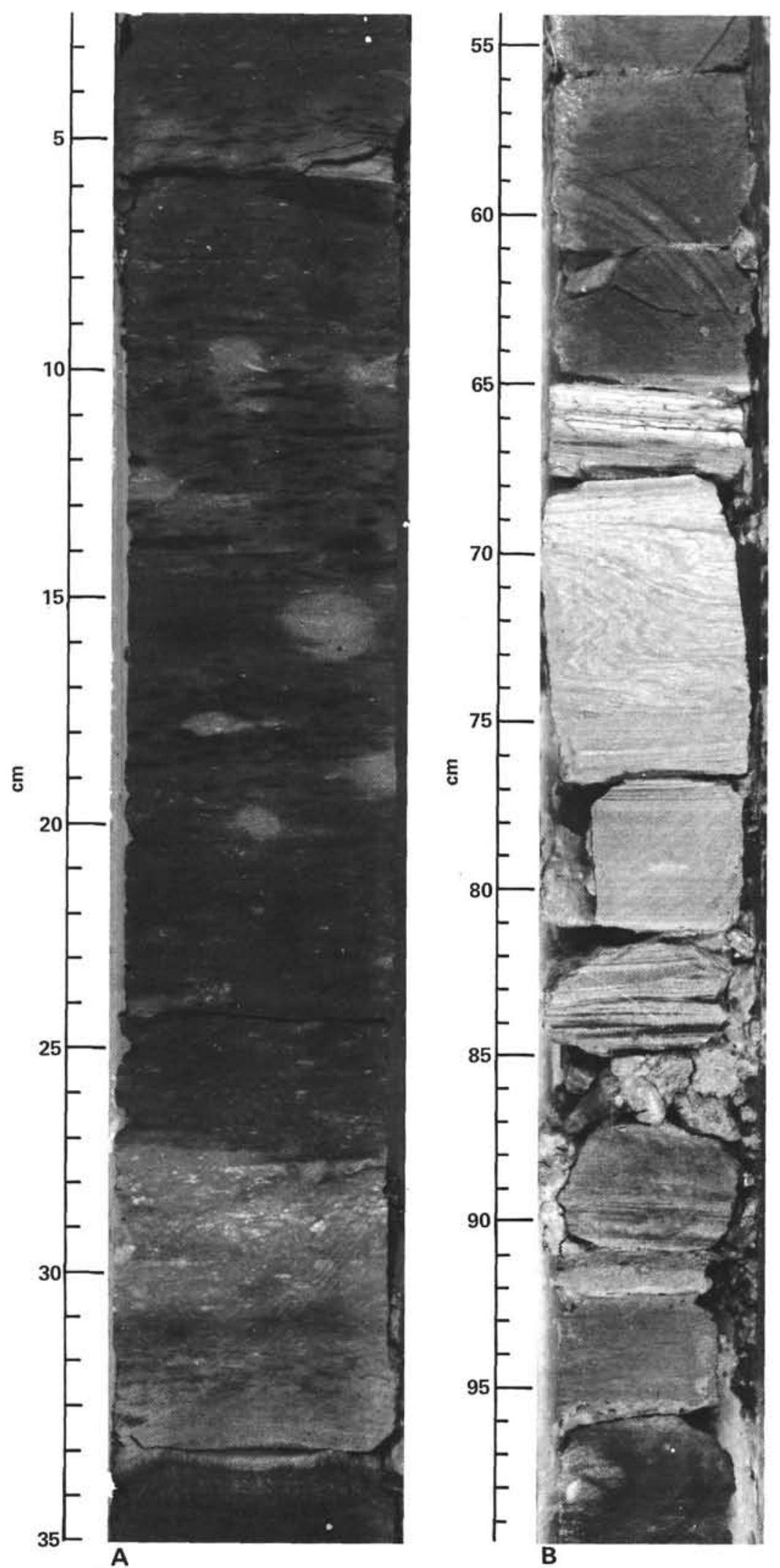

Figure 5. Core photographs of the upper Eocene Bermuda Rise Formation. A. Typical relatively Fe-, Mn-, and trace metal-enriched claystones showing typical varicolored shades. (Note the intense small-scale burrowing [e.g., 8-14 cm] and the pale spherical to elliptical reduction spots formed later during diagenesis. The "speckled" interval from 28 to $31 \mathrm{~cm}$ is similar to much of the upper Eocene Blake Ridge Formation, seen in Core 19 [Core 20, Section 3, 3-35 cm].) B. Terrigenous-derived turbidite (Blake Ridge Formation) within greenish, siliceous siltstone and mudstone. (Note the partial Bouma sequence [Tb-Td] from $65-81 \mathrm{~cm}$. This comprises a lower plane-laminated interval, then a prominent convolutelaminated interval, returning to plane laminations. The interval from 81 to $91 \mathrm{~cm}$ above shows cross lamination attributed to bottom-current reworking [Core 19, Section 2, 55-99 cm].) 

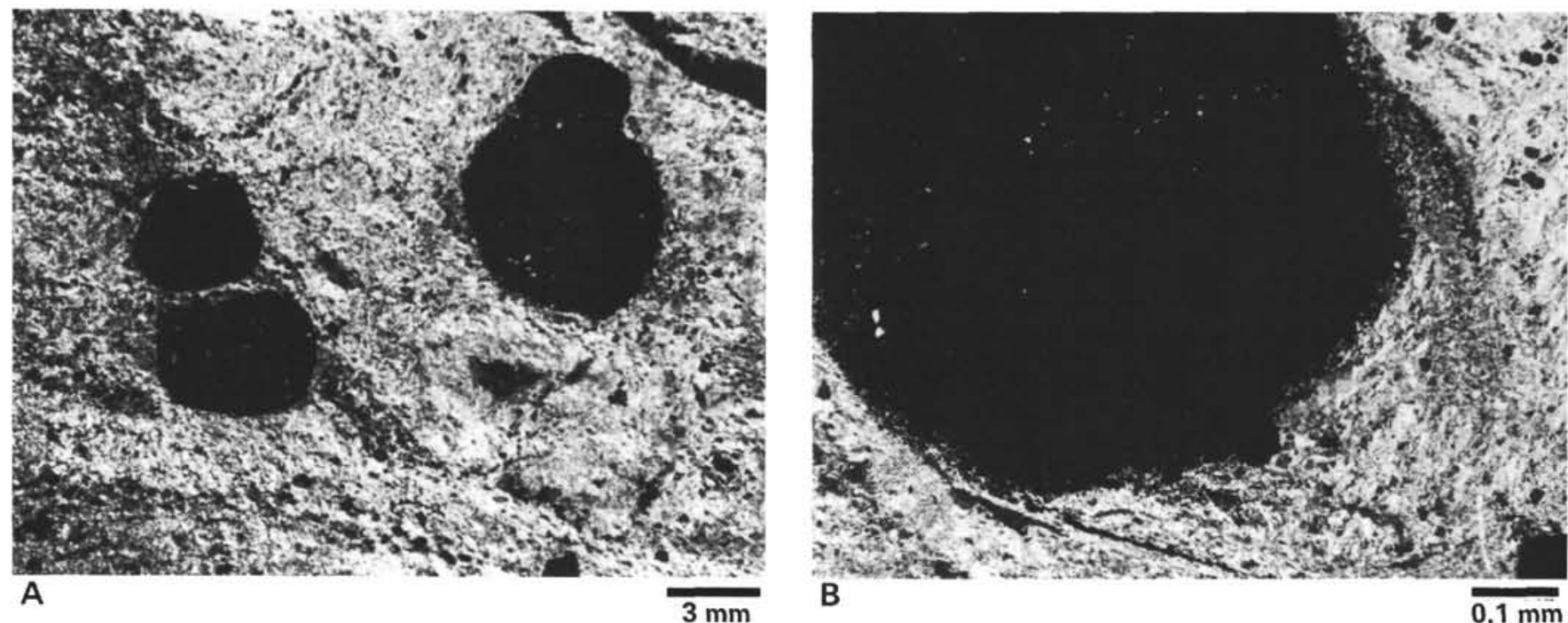

B

$0.1 \mathrm{~mm}$
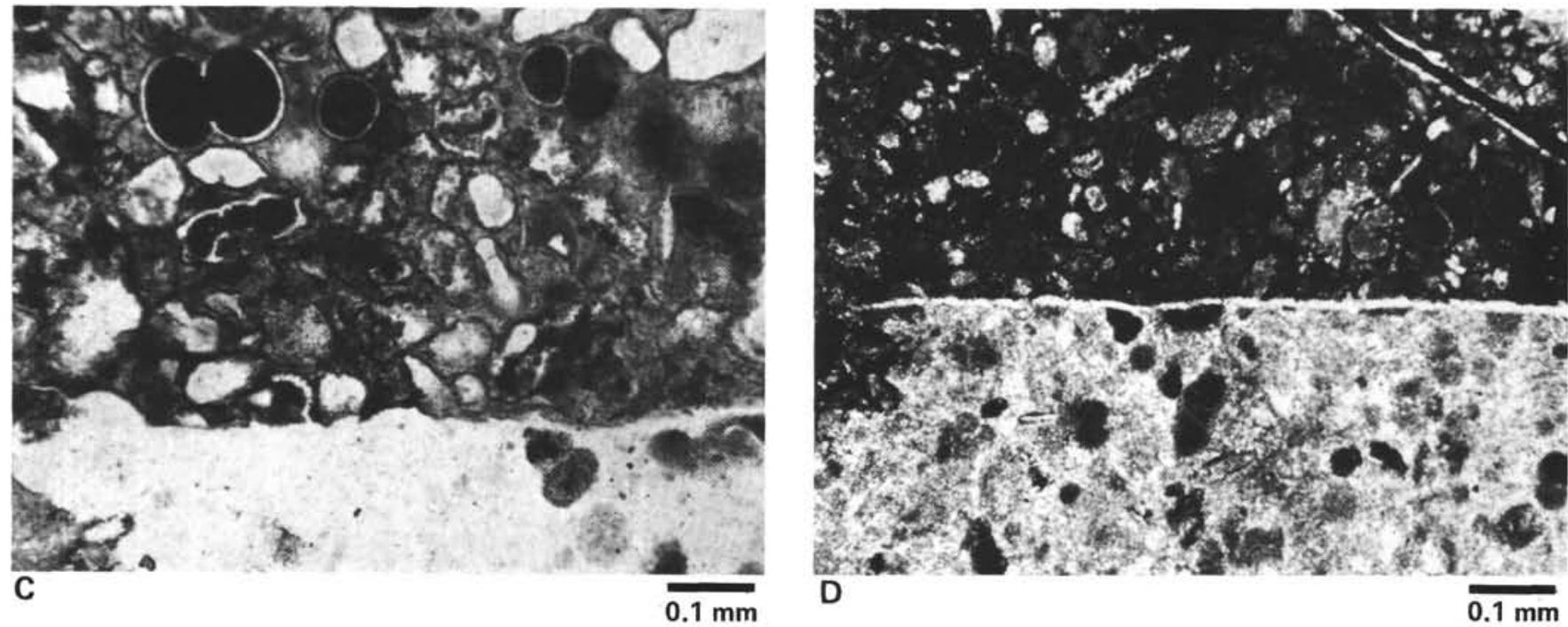

Figure 6. Photomicrographs. A. Manganese micronodules in claystone. (Note the way clay swirls around the Mn-micronodules, confirming they formed presignificant compaction.) B. Detail of manganese micronodules. (Note the virtual absence of included detrital material except at the edges.) (A and B are in plane-polarized light; Core 24, Section 2, 26-28 cm.) C. Chert in plane-polarized light. (A thin vein of chalcedonic quartz divides the area into a chertified and nonchertified sector. The chertified sector [pale] consists mostly of fine-grained chalcedonic quartz.) D. Same as C, but under crossed nicols. (Note the surviving patches of less chertified material in the chertified sector [paler].) (C and D-Core 23, Section 1, 2-4 cm.)

and in others quartz reaches $15 \%$. In the claystones, nannofossils comprise up to $10 \%$. Minor constituents seen in smear slides include feldspar, mica, glauconite, unspecified carbonate, pyrite, goethite, zircon, and sphene.

When impregnated samples are viewed in thin section, all the siliceous claystones contain appreciable amounts of terrigenous material (Fig. 7A). The terrigenous component is dominated by angular quartz grains, occasionally partly replaced by carbonate at the edges of grains. Muscovite is abundant, together with minor biotite. Coarser-grained intervals contain identifiable feldspar, mostly fresh plagioclase in the andesine-labradorite range (maximum extinction-angle determinations), but orthoclase, perthite, and rare microcline are also seen (e.g., microcline-Core 25, Section 1, 8-10 cm). Other rarer terrigenous grains include zircon and tour- maline. The larger terrigenous grains with little clay matrix are typically concentrated in the burrows (Fig. 7C). Some intervals (e.g., Core 24 , Section $4,36-38 \mathrm{~cm}$ ) contain scattered glauconite. Biogenic material comprises ubiquitous sponge spicules, scattered opaque phosphatic material, including fish teeth and rare radiolarians, preserved only as clay- or zeolite-filled molds. Many of the finer-grained massive varicolored claystones contain abundant, fine-grained zeolites with an interlocking felted texture. Rare larger euhedral ?zeolite crystals are also visible. Although the presence of very fine-grained volcanic material cannot be ruled out, no evidence of this is seen in the Upper Cretaceous and Eocene interval. Other diagenetic features include scattered dolomite rhombs and some minor carbonate cement. Where not too burrowed, there is a well-defined grain orientation. Some of the zeolitic claystones have a pelletal texture when 

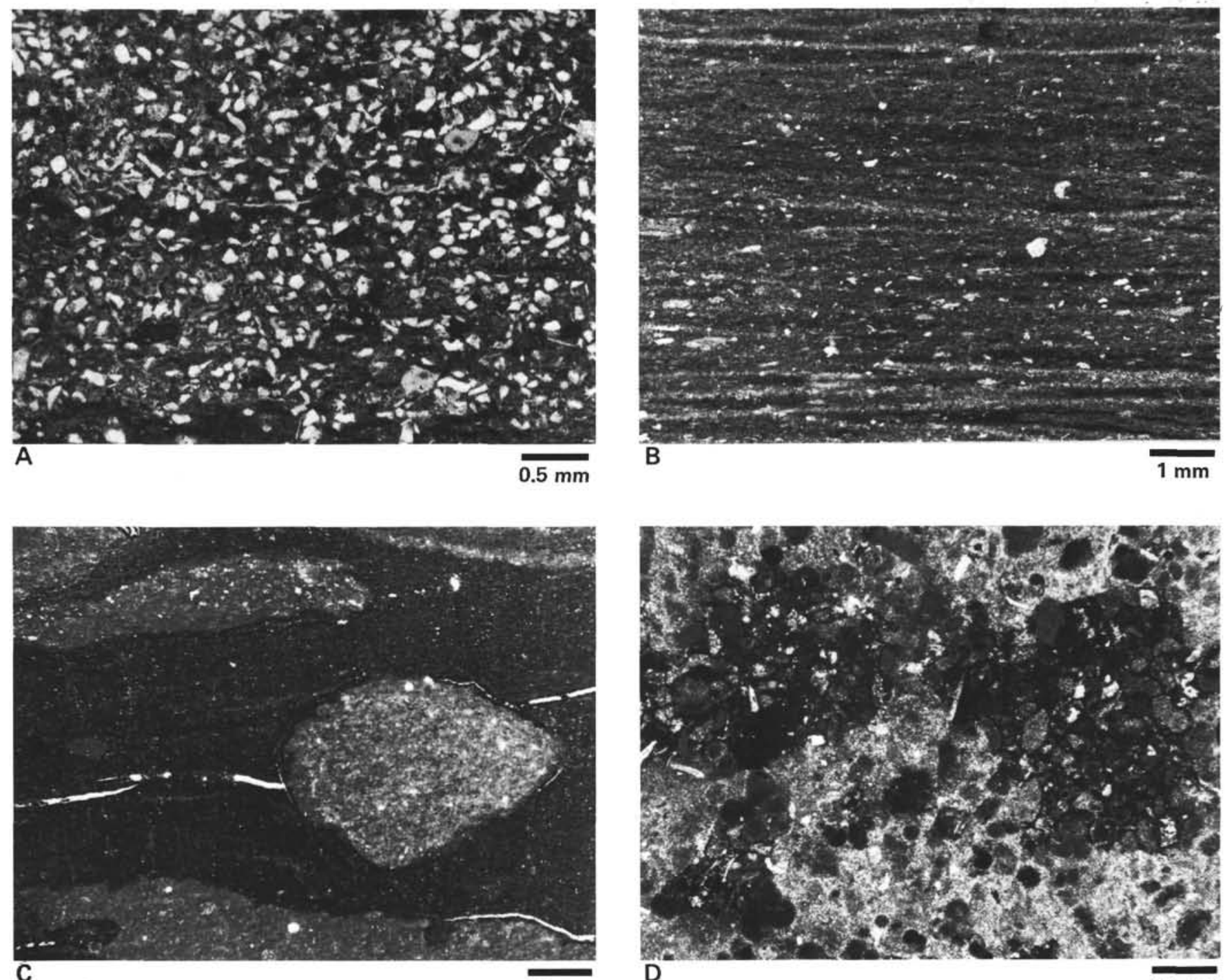

$0.1 \mathrm{~mm}$

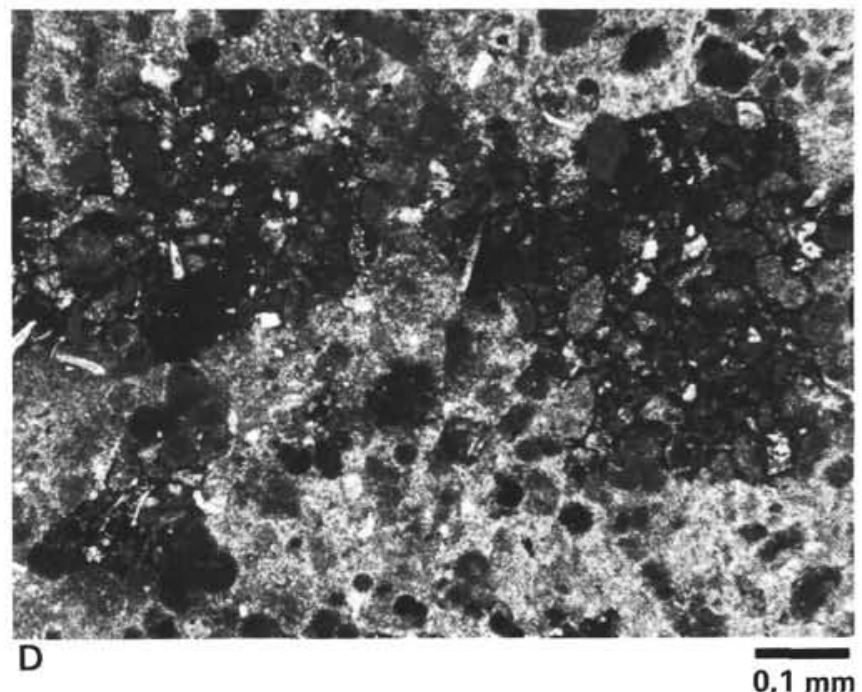

Figure 7. Photomicrographs of Maestrichtian and upper Eocene sediments. A. Quartzose silt with clay matrix. (Note angularity of grains. Shot in plane-polarized light; Core 19, Section 1, 47-49 cm.) B. Laminated claystone (pink). (Note streaky texture [in plane-polarized light]; Core 20, Section 2, 65-67 cm.) C. Burrowed claystone; burrows composed of slightly coarser material (plane-polarized light; Core 20, Section 1, 22-24 $\mathrm{cm})$. D. Chert under crossed nicols. (The fabric originally comprised pellets and planktonic foraminifers with scattered quartz grains. Paler patches now recrystallized to fine chalcedonic quartz. Core 23, Section 1, 2-4 cm.)

viewed at high magnification (e.g., Core 20, Section 2, $100-102 \mathrm{~cm}$ ). The manganese micronodules (Core 24, Section 2, 26-28 cm) are almost entirely opaque, with virtually no included terrigenous material (Fig. 6B).

\section{Siliceous Sediments}

Several intervals of unlithified porcellanous claystones are present in Cores 19 and 20 (Bermuda Rise Formation). However, only a few fragments of true chert were recovered in Cores 23 through 26, and these are probably not in situ. The zero recovery in Core 21 and the minimal recovery in Cores 22 and 23 (upper unit of Plantagenet Formation) is consistent with an interval dominated by highly resistant chert. The wire-line logs shed little light on this, probably because of highly irregular hole diameter. In Core 26 , drill breccia included a chip of white porcellanite (Core 26 , Section $1,43 \mathrm{~cm}$ ). The core catcher of Core 23 has a single fragment of porcellanite $5 \mathrm{~cm}$ in diameter. This sample is dark yellowish brown with very pale orange patches, vitreous and broken with a conchoidal fracture. The pale orange patches are incompletely silicified.

In thin section, the chert shows varied depositional and diagenetic features. The original texture was dominated by planktonic foraminifers, including Globotruncana and Heterohelix, with subordinate radiolarians and sponge spicules. There are small intraclasts of still unchertified fine-grained siltstone or claystone in which grains of quartz, muscovite, and feldspar are visible. Scattered small intraclasts of microspar are seen, as well as angular grains of polycrystalline quartz (Fig. 7D).

The rock is divided into more and less silicified "sectors" by thin veins filled with chalcedonic quartz (Fig. $6 \mathrm{C}, \mathrm{D})$. Within the less silicified sectors, planktonic for- 
aminifers are replaced by fine-grained quartz. The interior cavities are either opaque under crossed nicols (opal-CT), or consist of brown chalcedonic quartz in plane-polarized light. Radiolarians and sponge spicules are preserved as fine-grained gray chalcedonic quartz. Silification is much more advanced in the other sectors where foraminiferal shells are more coarsely recrystallized and the interiors are infilled with spherulitic chalcedonic quartz. All the matrix is silicified, often now replaced by patches of coarser-grained chalcedonic quartz, some of it spherulitic. In both the more and less silicified "sectors" there are scattered dolomite rhombs and some calcite. In some cases, the carbonate has replaced quartz later in diagenesis, particularly the shell walls of some planktonic foraminifer already replaced by chalcedonic quartz.

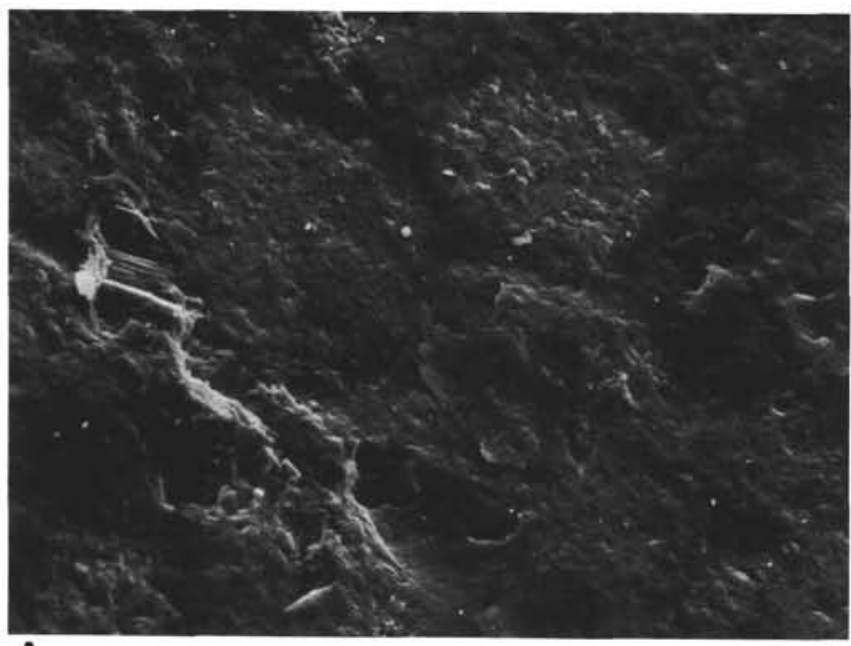

A

$\overline{200 \mu \mathrm{m}}$

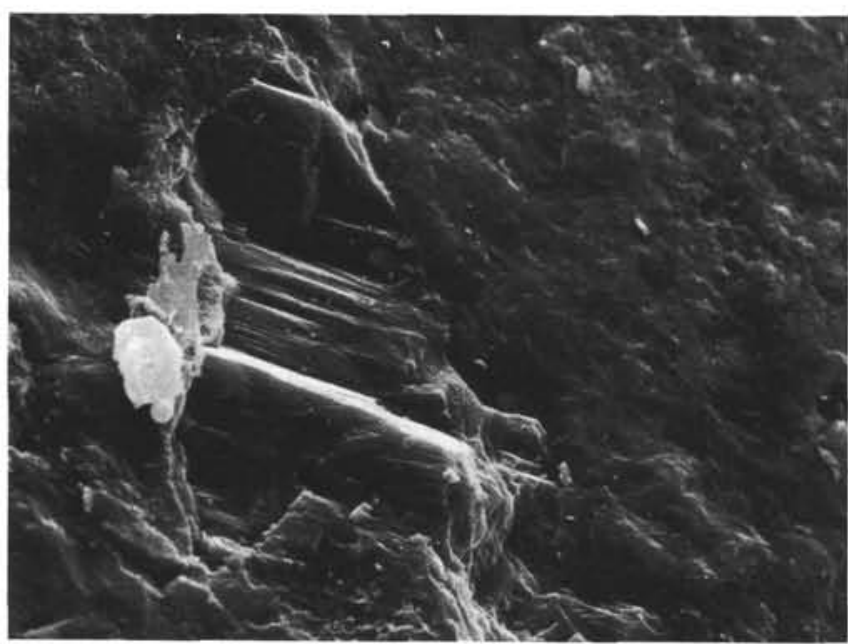

C

$\overline{100 \mu \mathrm{m}}$
With the scanning electron microscope the bioclasts are distinguished by patches of pale, slightly more coarsely crystalline texture (Fig. 8). Blocky chalcedonic quartz and well-cleaved carbonate are also seen (Fig. 8).

\section{Micritic Limestones}

Although most of the siliceous siltstones and claystones are at least weakly calcareous (they fizz gently in $5 \% \mathrm{HCl}$ ), several intervals restricted to Core 19 (Eocene, Bermuda Rise Formation) contain micritic limestone. Notably in Core 19 , Section $3,48-55 \mathrm{~cm}$ white, medium-grained, siliceous chalk passes into finer-grained siliceous chalk, with brown, fine-grained siltstone intraclasts. This interval shows grading, and plane and micro-cross lamination. A smear slide of gray green, finegrained sediment from Core 19 , Section $2,79 \mathrm{~cm}$ was
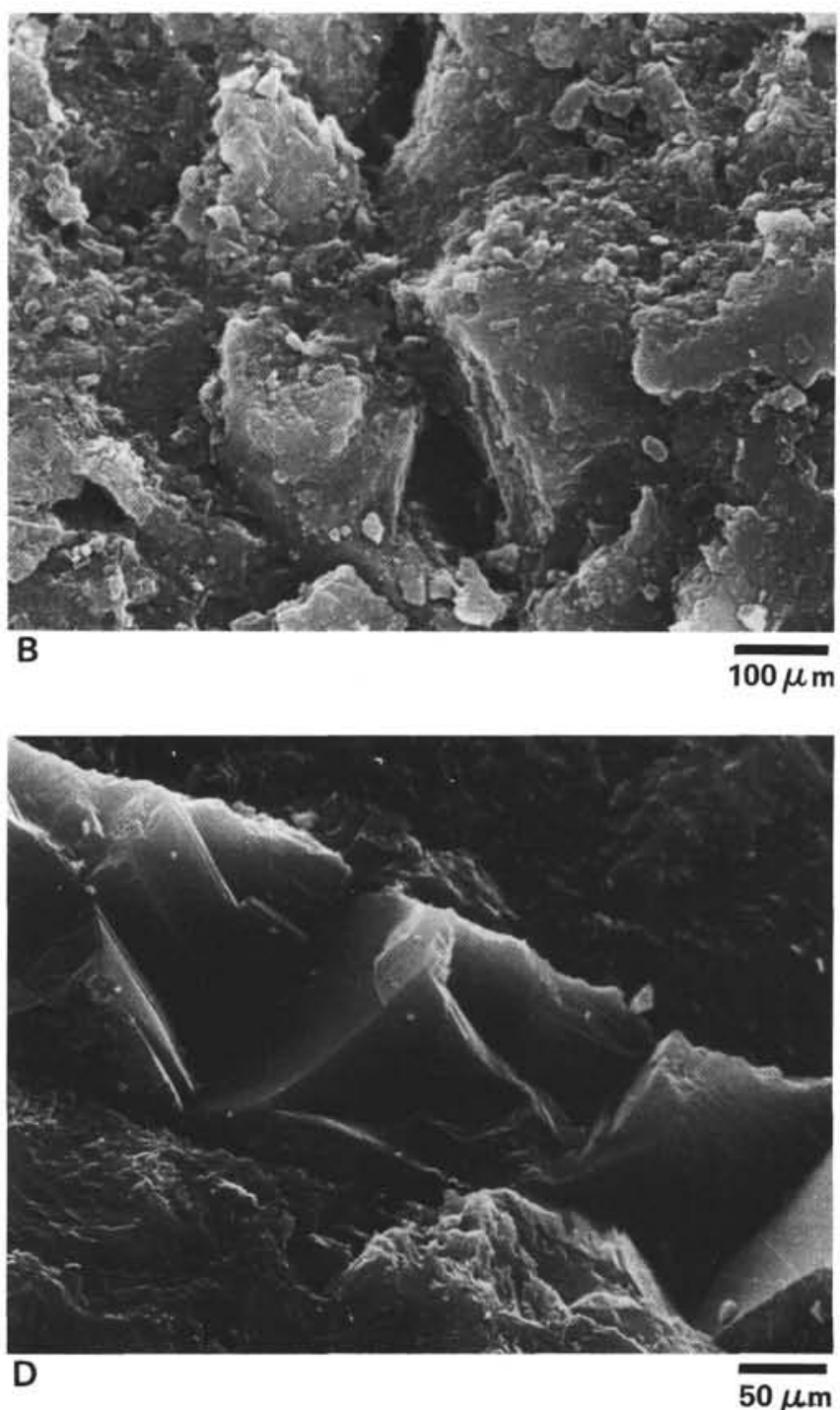

Figure 8. Scanning electron micrographs of chert. A. Typical chert fabric at lower magnification, showing featureless matrix and vague (pale) impressions of bioclasts (in thin section, these are seen to be mostly planktonic foraminifers). B. Typical fabric of a more replaced and recrystallized "sector" of the chert sample. The micrograph shows a fabric of microcrystalline quartz, possibly partly etched, associated with the formation of later diagenetic carbonate. C. Formation of later diagenetic carbonate in featureless replacement chert, formed of fine-grained, chalcedonic quartz. D. Vein containing cleaved secondary carbonate in the chalcedonic quartz chert (Core 23, Section 1, 2-4 cm). 
found to consist of $60 \%$ unspecified carbonate (calcite), largely recrystallized.

A thin section (Core 19, core catcher) comprises finegrained quartzose silt with mica, minor feldspar, and scattered glauconite pellets. The quartz grains are concentrated in small burrows. Within these "mottles" the quartz grains are cemented by fine-grained zeolite and rarely by chalcedonic quartz. Some of the silica is dark under crossed nicols, and is probably opal-CT. There are scattered radiolarians replaced by chalcedonic quartz, although these have been mostly plucked out during sectioning. One other thin section (Core 20, Section 2, 46 $\mathrm{cm}$; Bermuda Rise Formation), is a quartz silt-rich pelmicrite, with $60 \%$ micrite, $10 \%$ quartz, $15 \%$ pellets, $10 \%$ micrite-filled planktonic foraminifers, $6 \%$ glauconite, and $2 \%$ organics. There are also rare calcite-replaced radiolarians and thick-walled shell fragments. The pellets are small carbonate intraclasts. The foraminifer shells are often micritized. Glauconite fills some foraminiferal shells. The sediment is laminated with a "stringy" texture picked out by differential cementation of more quartz-rich and clay-rich laminae.

\section{Siliceous Mudstones and Siltstones}

The upper part of Core 19 (Section 1, $6 \mathrm{~cm}$; Section $2,80 \mathrm{~cm}$ ) is composed of greenish mudstones and quartzitic siltstones, which contrast strongly with the varicolored claystones of the Plantagenet and the lower part of the Bermuda Rise Formation (Fig. 1). The mudstones are well-laminated, with siltstone partings on the average 0.5 to $1 \mathrm{~cm}$ thick. Some intervals are speckled with tiny white "flecks" up to several millimeters across. Five graded intervals up to $18 \mathrm{~cm}$ thick are seen in Core 19. The thickest in Section 2, 82 to $62 \mathrm{~cm}$, shows grading, and parallel and convolute lamination (Figs. 5B, 9A). In this case the Ta-Td intervals of the Bouma sequence are present. Other intervals of Core 19 are moderately to highly burrowed (Fig. 9B) (e.g., Core 19, core catcher). Below Core 19, more variegated silty claystones predominate.

In thin section, the siliceous sediments are almost entirely terrigenous, with angular quartz grains, muscovite, rare biotite, plagioclase, perthite, and occasional orthoclase. Plagioclases are in the orthoclase-labradorite range. Polycrystalline quartz grains and clay clasts are visible. Bioclasts are restricted to sponge spicules, rare fish teeth, and bone material; radiolarians are not preserved. Glauconite pellets are numerous, together with scattered dolomite rhombs and minor calcite cement. The matrix includes finely crystalline zeolites and occasional larger euhedral crystals. Burrowing is extensive, with coarser quartz grains usually concentrated in burrows.

\section{X-RAY DIFFRACTION}

Laboratory whole-rock X-ray diffraction confirmed shipboard results. The clay minerals of the variegated claystones are illite with subordinate kaolinite. Core 20, Section 1, at $135 \mathrm{~cm}$ (Bermuda Rise Formation) gave, in decreasing order of abundance, quartz, clinoptilolite, smectite, mixed-layer clays, and minor calcite. In other samples feldspar was also confirmed. From Cores 24 and 25, the Maestrichtian upper unit of the Plantagenet Formation, Chamley (this volume) recorded $40 \%$ smectite, $30 \%$ kaolinite, and $25 \%$ illite. In the Eocene of Core 20 (Bermuda Rise Formation) he found $80 \%$ smectite, $15 \%$ illite, $5 \%$ palygorskite, and traces of sepiolite and kaolinite as well. In addition, clinoptilolite and opal-CT are abundant.

\section{CHEMICAL ANALYSIS}

\section{Major Elements}

The laboratory determinations of organic carbon (Table 1) show that values are minimal in the upper Eocene interval (Blake Ridge, Bermuda Rise, and the upper unit of the Plantagenet formations, Core 19), but increase to $0.6 \%$ in the Maestrichtian lower unit of the Plantagenet Formation. The sediments are virtually free of $\mathrm{CaCO}_{3}$, except for the graded micritic limestones of Core 19 (upper Eocene, Blake Ridge Formation).

Twelve major and trace element analyses were carried out on Maestrichtian to upper Eocene sediments, plus one of the overlying Great Abaco Member Miocene pelagic carbonates for comparison. Of the 12, 2 are from the upper Eocene basal Blake Ridge Formation (Core 19), 1 from the Bermuda Rise Formation (Core 20), 3 from the Eocene upper Plantagenet Formation, and 2 from the Maestrichtian Plantagenet Formation (Core 24). Three samples of the highest Hatteras Formation sediments were also analyzed (Cores 27,29 ). Results are given in Table 2 . Analysis followed a previously described method (Norrish and Hutton, 1969).

All the Maestrichtian to upper middle to upper Eocene samples analyzed are siliceous mudstones, siltstones, or claystones, with the exception of one sample of micritic limestone. Correlations of major elements, plotted in Figure 10, confirm an important terrigenous component in all the samples, including the variegated claystones. $\mathrm{SiO}_{2}$ values range up to $74.7 \%, \mathrm{Al}_{2} \mathrm{O}_{3}$ to $19.8 \%$, and $\mathrm{Fe}_{2} \mathrm{O}_{3}$ to $9.3 \%$ (Table 2). Most of these sediments would be termed cherts if more lithified. Samples from the lower Maestrichtian unit of the Plantagenet Formation contain less than $1 \% \mathrm{CaO}$. In the zeolitic claystones, $\mathrm{MgO}$ reaches $3.94 \%, \mathrm{~K}_{2} \mathrm{O} 5.4 \%$, and $\mathrm{TiO}_{2}$ $1.02 \% . \mathrm{P}_{2} \mathrm{O}_{5}$ is significantly higher in the Blake Ridge Formation and the Bermuda Rise Formation sediments (to $0.63 \%$ ), relative to both the Tertiary and the Maestrichtian units of the Plantagenet Formation (maximum of $0.21 \%$ falling to $0.06 \%$ downward). $\mathrm{MnO}$ values increase upward from $0.03 \%$ in Cores 27 to 29 in the black mudstones of the Hatteras Formation to higher values, with a maximum of $4.3 \%$ (Core 24 , Section 2, $26-28 \mathrm{~cm}$ ), in samples with manganese micronodules in the lower unit of the Plantagenet Formation (Maestrichtian). In general, major-element variation in one core (20) from the Bermuda Rise Formation is much greater than in the 3 cores $(24,27,29)$ of both the lower unit of the Plantagenet Formation and the top of the underlying Hatteras Formation.

The graphs in Figure 10 show that $\mathrm{Al}_{2} \mathrm{O}_{3}$ correlates with $\mathrm{TiO}_{2}, \mathrm{Fe}_{2} \mathrm{O}_{3}$ and $\mathrm{K}_{2} \mathrm{O}$ for most samples, but other 

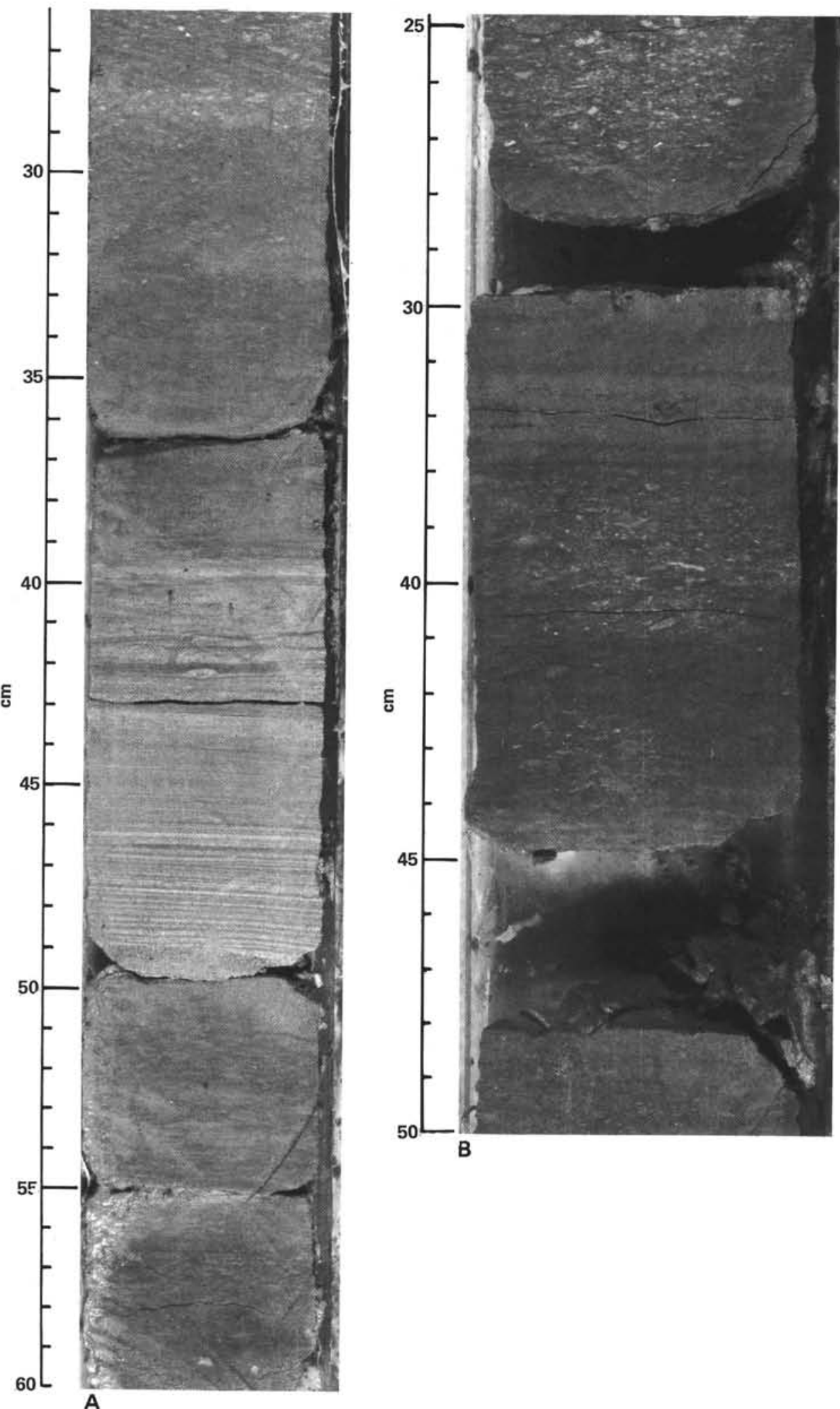

Figure 9. Core photographs of siliceous upper Eocene sediments of the definite Blake Ridge Formation. A. Graded and plane-laminated terrigenous-derived turbidite $(50-43 \mathrm{~cm})$ within very highly burrowed "speckled" siliceous siltstones and mudstones typical of the Bermuda Rise Formation at Site 534 (Core 19, Section 2, 26-60 cm). B. Typical "speckled" siliceous siltstone and mudstone of the upper Eocene Blake Ridge Formation. (The pale speckles are numerous tiny burrows, picked out by concentrations of slightly coarser and purer quartzose silt, seen in thin sections. The 31-33-cm interval shows some current lamination [Core 19, Section 1, 25-50 cm]). 
Table 1. Laboratory organic carbon and carbonate analyses for Hole 534A expressed as weight percent.

\begin{tabular}{lcccr}
\hline $\begin{array}{c}\text { Sample } \\
\text { (core-section, } \\
\text { interval in cm) }\end{array}$ & $\begin{array}{c}\text { Sub-bottom } \\
\text { depth (m) }\end{array}$ & Total & $\begin{array}{c}\text { Organic } \\
\text { carbon }\end{array}$ & $\mathrm{CaCO}_{3}$ \\
\hline $19-1,100$ & 697.50 & 0.060 & 0.048 & 0.101 \\
$19-3,53$ & 700.03 & 6.925 & 0.038 & 57.372 \\
$20-2,73$ & 707.73 & 0.354 & 0.046 & 2.568 \\
$20-3,70$ & 709.20 & 0.098 & 0.052 & 0.382 \\
$23-1,23$ & 732.73 & 0.094 & 0.110 & -0.133 \\
$24-1,64$ & 742.14 & 0.058 & 0.062 & -0.034 \\
$24-3,62$ & 745.12 & 0.059 & 0.072 & -0.118 \\
$25-1,131$ & 751.81 & 0.244 & 0.242 & 0.023 \\
26, CC $(0.0)$ & 760.59 & 0.206 & 0.243 & -0.311 \\
$27-1,15$ & 764.65 & 0.492 & 0.392 & 0.923 \\
$27-1,112$ & 765.62 & 0.641 & 0.579 & 0.519 \\
\hline
\end{tabular}

major element oxides show no such correlation. For example, $\mathrm{MnO}, \mathrm{P}_{2} \mathrm{O}_{5}$, and $\mathrm{SiO}_{2}$ vary independently of $\mathrm{Al}_{2} \mathrm{O}_{3}$. The correlations shown in Figure 10 confirm the dominant terrigenous provenance shown by petrography. Exceptions are the zeolitic samples, which are enriched in $\mathrm{K}_{2} \mathrm{O}$ relative to $\mathrm{Al}_{2} \mathrm{O}_{3}$ (e.g., Core 20, Section 3, 61-63 cm, upper Plantagenet Formation), and several samples that are relatively enriched in $\mathrm{TiO}_{2}$. This could conceivably reflect a Ti-rich fine volcanic component, but this was not otherwise confirmed.

\section{Trace Elements}

Highest values of $\mathrm{Ni}$ (137 ppm), $\mathrm{Cr}$ (238 ppm), V (394 ppm), Sc (227 ppm), Zn (226 ppm), and $\mathrm{Pb}(87 \mathrm{ppm})$ all occur in the sample containing $4.33 \% \mathrm{MnO}$ and discrete manganese micronodules. V correlates with total iron oxide abundance. Within the top of the Hatteras Formation there are no significant differences in most trace elements contents between Cores 27 and 29, and those

Table 2. Chemical analyses of Hole 534A Upper Cretaceous and upper Eocene and Cretaceous Plantagenet, Bermuda Rise, and Blake Ridge sediments.

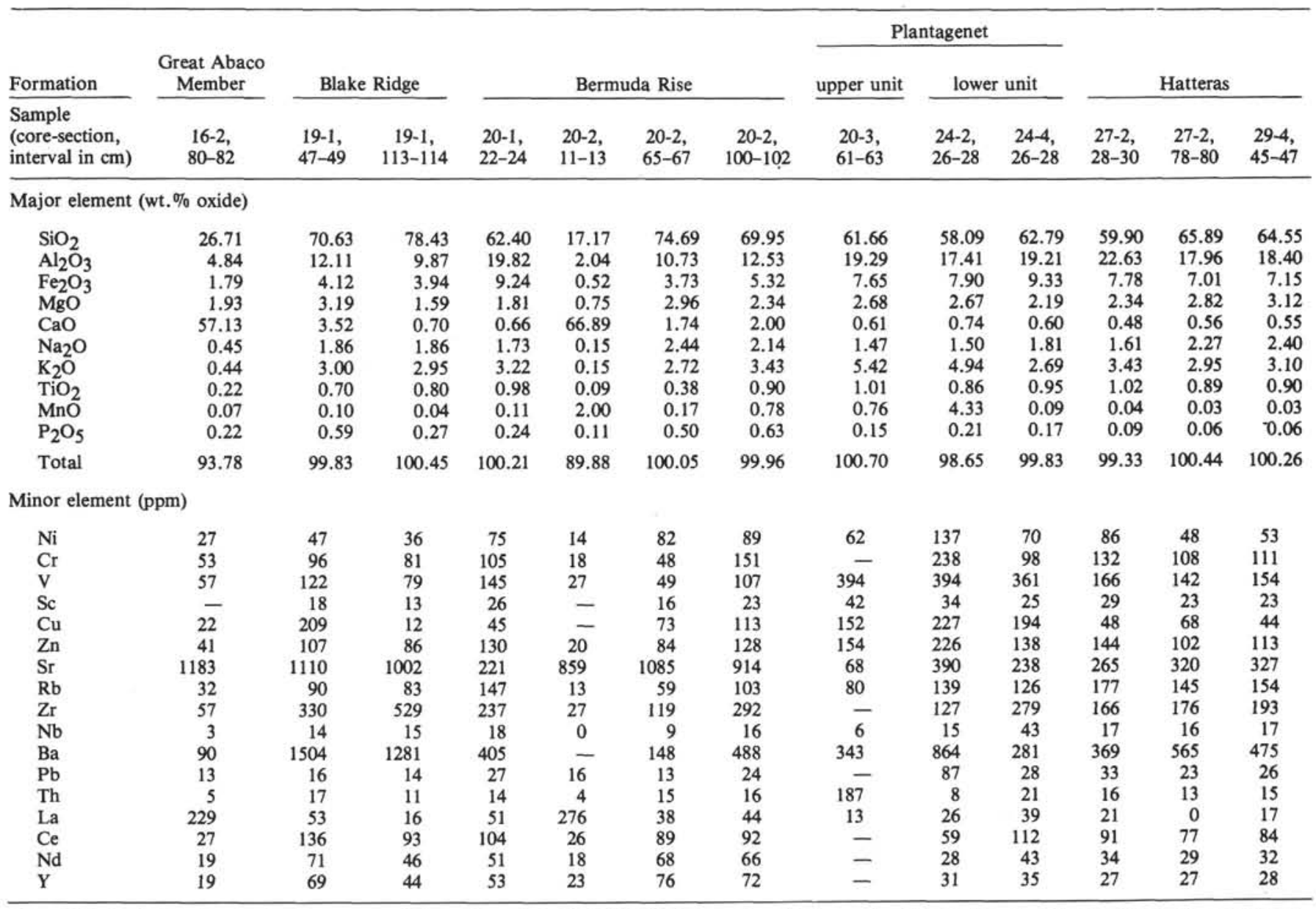

Note: Lithologies for the samples shown are as follows: Sample 534A-16-2, 80-82 cm: redeposited nannofossil chalk from the Miocene Great Abaco Member. 19-1, 47-49 cm and 19-1, 113-114 cm: greenish siliceous mudstones, burrowed, glauconitic, and phosphatic, upper Eocene Blake Ridge Formation. 20, 1, $22-24 \mathrm{~cm}, 20-2,65-67$, and $20-2,100-102 \mathrm{~cm}$ : variegated siliceous and zeolitic claystones and mudstones, upper Eocene Bermuda Rise Formation. 20-3, 61-63 cm: Eocene and upper Plantagenet Formation. 24-2, 26-28 cm and 24-4, 26-28 cm: variegated claystone with discrete manganese micronodules, ?Maestrichtian lower Plantagenet Formation, 27-2, 28-30 cm, 27-2, 78-80 cm, and 29-4, 45-47 cm: dark organic-rich claystone, Upper Cretaceous of the Hatteras Formation. One analysis of the Miocene nannofossil carbonates of the Great Abaco Member and three of the Upper Cretaceous black shales from the Hatteras Formation are included for comparison. - indicates sample not analyzed. 

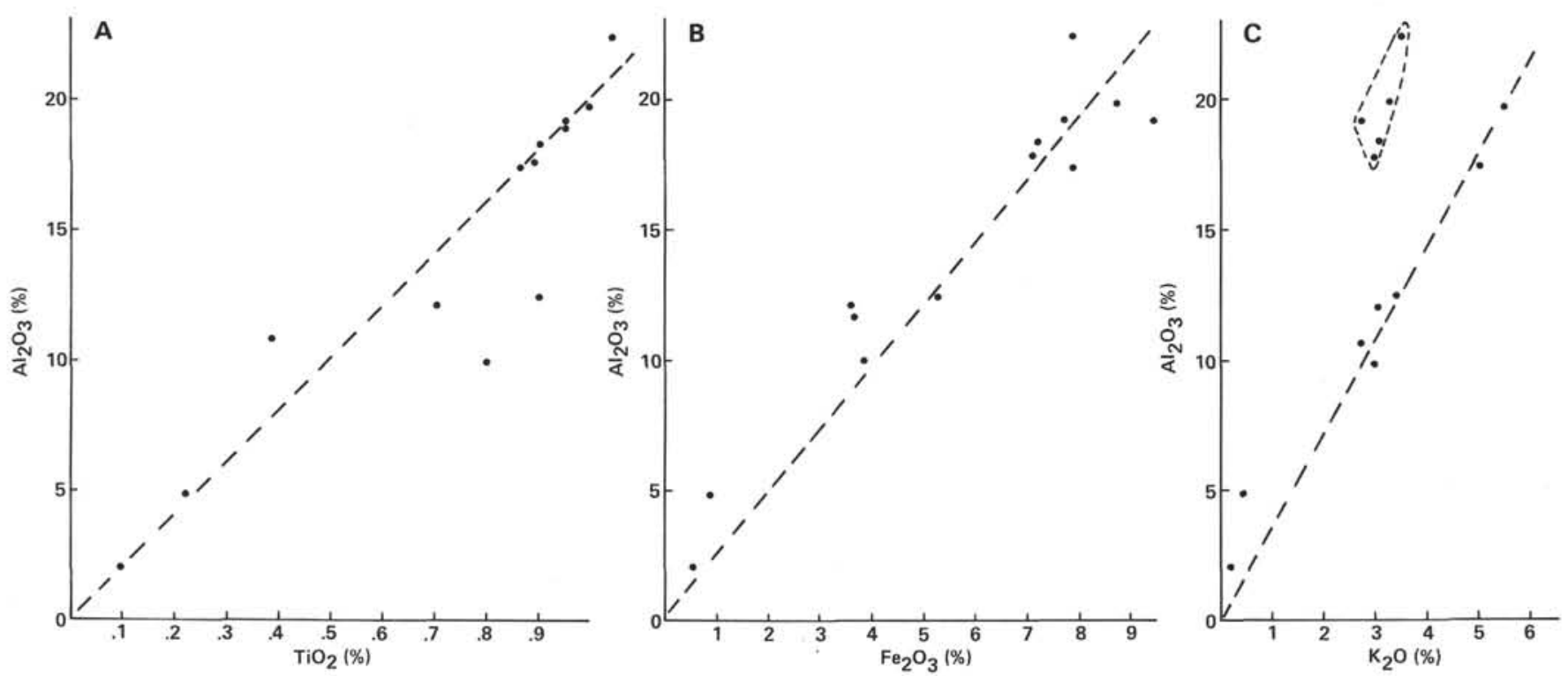

Figure 10. Graphs showing major-element correlations of upper Eocene and Maestrichtian sediments of the Blake Ridge, Bermuda Rise, and upper and lower Plantagenet formations. (The reference lines are not calculated regression lines.) $\mathrm{A}$. $\mathrm{Al}_{2} \mathrm{O}_{3}$ correlates with $\mathrm{TiO}_{2}$, as expected, for terrigenous-derived material, with the exception of the two samples from the Blake Ridge Formation (Core 19) and one sample from the Eocene Bermuda Rise interval (20-2, 100-102 cm); this additional $\mathrm{TiO}_{2}$ could possibly come from fine-grained volcanic material, which was not otherwise detected. $\mathrm{B}$. $\mathrm{Al}_{2} \mathrm{O}_{3}$ shows a general correlation with $\mathrm{Fe}_{2} \mathrm{O}_{3}$ for all samples, indicating that, unlike $\mathrm{MnO}$, most of the iron is associated with the terrigenous phase. (In contrast, $\mathrm{MnO}$ varies independently of $\mathrm{Al}_{2} \mathrm{O}_{3}$ in samples with $\mathrm{Mn}$ values $>1000 \mathrm{ppm}$. This manganese oxide, including the micronodules, is thought to be hydrogenous.) $\mathrm{C} . \mathrm{Al}_{2} \mathrm{O}_{3}$ correlates with $\mathrm{K}_{2} \mathrm{O}$, with the exception of Eocene sediments containing abundant diagenetic clinoptilolite. (Other major elements shown in Table 2 but not plotted here show no significant correlation; notably $\mathrm{SiO}_{2}$ and $\mathrm{P}_{2} \mathrm{O}_{5}$ do not correlate with $\mathrm{Al}_{2} \mathrm{O}_{3}$.)

above (e.g., Core 24) in the lower Plantagenet Formation. Exceptions are $\mathrm{Cu}$, which goes up from 44 to 68 ppm in the organic-rich Hatteras sediments to 194 to $227 \mathrm{ppm}$ in the organic-poor lower Plantagenet claystones. $\mathrm{V}$ also shows a similar trend (142-166 up to 361-394 ppm).

Trace element values in the Bermuda Rise Formation (Cores 20-23) are more variable; almost all are depleted in trace elements relative to Pacific pelagic clays. Values of some elements appear to vary randomly, for example, $1085 \mathrm{ppm}$ of $\mathrm{Sr}$ in a siliceous claystone (Core 20, Section 2, 65-67 cm) containing only $1.74 \% \mathrm{CaO}$.

Trace elements of the one analyzed micritic limestone sample (Core 11, Section 2, 11-13 cm, Bermuda Rise Formation) are similar to those of the overlying Great Abaco Member redeposited Miocene nannofossil oozes (e.g., Core 16, Section 2, 80-82 cm). Relative to the interbedded Eocene mudstones, $\mathrm{Sr}$ and La are strongly enriched in these carbonates. The reason for $\mathrm{La}$ enrichment is not clear. Relative to deep-sea Pacific clays, the trace elements of the siltstones, mudstones, and claystones are relatively depleted (Turekian and Wedepohl, 1961).

The two samples of greenish siliceous silty mudstones deposited in the late middle to late Eocene (basal Blake Ridge Formation) are distinctive, having the highest $\mathrm{SiO}_{2}$ values (to $78.4 \%$ ), also high values of $\mathrm{Cu}$ (to 209 $\mathrm{ppm}$ ), $\mathrm{Sr}$ (to $1110 \mathrm{ppm}$ ), $\mathrm{Zr}$ (to $529 \mathrm{ppm}$ ), $\mathrm{Ba}$ (to 1504 $\mathrm{ppm}$ ), and $\mathrm{Ce}$ (to $136 \mathrm{ppm}$ ). Relative to deep-sea clays (Turekian and Wedepohl, 1961), only Sr is strongly enriched, which is unexpected in these virtually noncalcareous deposits. Only in these green sediments does $\mathrm{Ba}$ even nearly approach the average Pacific deep-sea clay value of $2300 \mathrm{ppm}$ (Turekian and Wedepohl, 1961). However, most of the trace metals are enriched relative to normal hemipelagic clays, muds, and silts of terrigenous provenance.

\section{REGIONAL COMPARISONS}

The DSDP sites where Upper Cretaceous to Eocene sediments attributed to the Plantagenet Formation and the Bermuda Rise Formation have been cored are summarized in Figure 2 (modified after Jansa et al., 1979). In general the Cretaceous Plantagenet variegated claystones occur widely, including the Blake-Bahama Basin at Hole 391C (Benson, Sheridan, et al., 1978). Zeolites are not reported at this nearby Hole 391C, but are abundant at Site 534, indicating marked local variation. Manganese micronodules similar to those at Site 534 are seen in some claystone beds in Holes 7A and 9A. Volcanic glass is common at sites close to the New England Seamounts (Sites 382, 385, 386). Some volcanic glass was reported from Site 391, but no evidence of this is seen at Site 534. Site 105 is particularly enriched in the metals $\mathrm{Mn}, \mathrm{Zn}, \mathrm{Cu}, \mathrm{Pb}, \mathrm{Cr}, \mathrm{Ni}$, and $\mathrm{V}$ (Lancelot et al., 1972). A complex mineral assemblage cored there (not recorded at Site 534) includes sphalerite, goethite, todorokite, pyrite, siderite, hematite, and iron-montmorillonite (Lancelot et al., 1972).

Sites at which the Bermuda Rise Formation has been penetrated are shown in Figure 3. The formation occurs mostly between the outer continental rise and the upper Eocene Mid-Atlantic Ridge. Jansa et al. (1979) note that the Bermuda Rise Formation appears to be missing be- 
neath a major unconformity under the continental rise and in the Blake-Bahama Basin and Cap Gap. The formation was not drilled at Site 391 in the Blake-Bahama Basin (Sheridan, Enos, et al., 1978). Coring of definite Bermuda Rise sediments at Site 534 was thus unexpected. This was particularly so since Dow (1978) used organic maturation profiles as an index of the thickness of sediment eroded at unconformities. The implication was that sharply increased maturation implied sediment erosion. In this way he inferred a loss of circa $800 \mathrm{~m}$ of section at Site 391. However, the Miocene profile used only one data point, and factors other than burial alone could possibly have effected maturation (Sheridan, Gradstein, et al., this volume). At Site 534, erosion could theoretically have taken place between the Upper Cretaceous and the upper Eocene interval, or between the upper Eocene and the Miocene, as neither Paleocene nor Oligocene sediments were recovered. The absence of Paleocene could be due to the poor recovery of Cores 20 through 23, but several minor sediment hiatuses could also exist. A single major erosional event in the Maestrichtian to Eocene is unlikely in view of the gradational contact observed between the formations. On the other hand, the Oligocene is not represented at Site 534, although recovery of the interval from the Miocene intraclastic chalks of the Great Abaco Member of the Blake Ridge Formation (Bliefnick, Robertson, and Sheridan, this volume) to the Eocene basal Blake Ridge Formation was quite good. There are no obvious signs of nondeposition (e.g., hardgrounds, Mn-coatings, etc.), so it is probable that the absence of Oligocene sediments is due to seafloor current erosion during the late Oligocene to the early Miocene. Sedimentation rates point to loss of up to $100 \mathrm{~m}$ of the succession, much less than the $800 \mathrm{~m}$ inferred at Site 391 (Benson, Sheridan, et al., 1978). High-quality, multireflection seismic profiles could possibly indicate where any missing sediment has been redeposited by geostrophic bottom currents.

\section{INTERPRETATION}

\section{Provenance}

All the siltstones, mudstones, and claystones show evidence of a similar terrigenous origin, which is seen even in the chert. The source rocks were ultimately plutonic and metamorphic, presumably once exposed in the southeastern United States. The terrigenous composition is virtually identical to that of the underlying Lower Cretaceous Blake-Bahama Formation (Robertson and Bliefnick, this volume) and the Jurassic (Ogg et al., this volume). Partial Bouma sequences, grading, and parallel and convolute lamination indicate deposition by turbidity currents. In many intervals the strong burrowing totally destroys primary lamination. The marly micritic limestones, seen in the upper Eocene (Core 19), are again turbiditic, derived from the continental rise or the Blake Plateau. According to Bliefnick, Robertson, and Sheridan, (this volume), the redeposited material of the overlying Miocene Great Abaco Member of the Blake Ridge Formation was derived both from the Great Abaco canyon area to the southeast of Site 534 and the Ba- hamas to the south. The upper Eocene calciturbidites in the Bermuda Rise Formation at Site 534 could have been derived from the same source as the Miocene calciturbidites. The glauconite pellets appear to have been transported from shallower water with the terrigenous material.

\section{Surface Productivity}

Although bioclastic silty mudstones identified by basal Blake Ridge Formation are restricted to sponge spicules and fish teeth, which are more resistant to solution, the siliceous and phosphatic nature, plus relative enrichment in $\mathrm{Ba}$, points to an originally high biogenic input. Radiolarians, which are abundant in the Bermuda Rise sediments, for example, at the type locality (Jansa et al., 1979), have presumably been totally dissolved close to the sediment/water interface. Ba is well known to be enriched in hydrothermal sediments as well as being associated with high biological productivity (Boström et al., 1973). In this case the major and other trace elements point to terrigenous and biogenic source materials.

In the variegated claystones of the Eocene Bermuda Rise Formation, radiolarians are seen occasionally as clay-filled molds, but are not well preserved. Phosphate and $\mathrm{Ba}$ are again relatively enriched. The evidence from Site 534 is in keeping with the concept of high plankton productivity inferred for other parts of the western equatorial Atlantic in the Eocene. The conventional explanation for this is that nutrient-rich surface waters were able to flow from the Pacific through an open Isthmus of Panama into the Caribbean, then into the equatorial Atlantic (Ramsay, 1973). The high productivity, which reached a maximum in the early middle Eocene, may have resulted from both equatorial and coastal updwelling (Riech and von Rad, 1979).

\section{Formation of Zeolite}

Unlike other DSDP sites in the western North Atlantic that have recovered various zeolites in Upper Cretaceous to Eocene sediments, at Site $\mathbf{5 3 4}$ clinoptilolite is the only zeolite to be recorded. There is now extensive evidence from both the Atlantic and Pacific oceans (summarized by von Rad and Rösch, 1972; Riech and von Rad, 1979; and Kastner, 1979) that clinoptilolite forms diagenetically well below the sediment surface, particularly in siliceous sediments. Opal A, released by dissolution of siliceous plankton, reacts with alumina and potassium ions to form either clinoptilolite alone or opal-CT plus clinoptilolite. The combination of biogenic silica, alumina, and potassium from terrigenous clays is thus an ideal source for clinoptilolite. Volcanic material is not required.

\section{Origin of Cherts}

The formation of cherts at Site 534 cannot be adequately explained. In particular, the amount of chert in the upper unit of the Plantagenet Formation (e.g., Cores 21-23) remains unknown. The larger piece of chert from Core 23 may not be representative. In this case, the chert was formed within a calciturbidite composed of large planktonic foraminifers with little ma- 
trix. This was probably a more porous horizon than the surrounding claystones, allowing silica-rich solution to be concentrated. Preferential chertification of porous planktonic foraminiferal calciturbidites has also been noted, for example, in the graded bases of lower Tertiary calciturbidites from Cyprus (Robertson, 1978).

As seen in many deep-sea cherts (e.g., Riech and von Rad, 1979), silica has replaced planktonic foraminiferal shells, whereas opal-CT (confirmed by X-ray diffraction) formed inside some tests. Veins of chalcedonic quartz appear to have formed relatively early in diagenesis, isolating adjacent areas from the supply of silica needed to complete conversion to chalcedonic quartz. In the more silicified sectors, some dissolution of finegrained quartz and precipitation of coarser-grained chalcedonic quartz has taken place. Partial replacement of the chalcedonic quartz by dolomite rhombs and minor calcite occurred later in diagenesis. In summary, the calciturbidites appear to have been preferentially silicified because of greater porosity and permeability than the surrounding clays. Radiolarians dissolved from the adjacent clays, and the silica then migrated into the calciturbidites, probably early in diagenesis. Most of the clays are highly siliceous and with further diagenesis would probably end up as chert.

\section{Metal Enrichment}

Relative to hemipelagic muds, both the greenish siliceous sediments and the multicolored claystones are relatively enriched in many metals (cf., Turekian and Wedepohl, 1961). Arthur (1979) summarized existing data (e.g., Lancelot et al., 1972; Murdmaa et al., 1978) and discussed three hypotheses for the metal enrichment: (1) the metals were derived from volcanic exhalations (Lancelot et al., 1972); (2) the metals were related to slow sediment accumulation (Murdmaa et al., 1978); and (3) they were controlled by upward diffusion from the underlying Upper Cretaceous black shales of the Hatteras Formation. As pointed out by Arthur (1979), the volcanic exhalative origin posited by Lancelot et al. (1972) is readily dismissed on account of the widespread occurrence of the metalliferous sediments, and the association with terrigenous, rather than volcanic material. Arthur (1979) felt that the metal accumulation was too great to be explained by slow accumulation alone, as suggested by Murdmaa (1978); instead he proposed upward diffusion of dissolved metals from the underlying anoxic Hatteras black shales. Points relevant to this proposal from the Site 534 data (Table 2) are: (1) Virtually none of the metal analyzed from the most brightly colored, variegated claystones exceed those reported in average deep-sea Pacific clays. (2) Highest metal values correlate with the presence of manganese micronodules. (3) The greenish nonvariegated siltstones of Core 19 (upper Eocene) also show metal enrichment. (4) Intervening biogenic carbonates show no signs of metal contamination (e.g., Core 20, Section 2, 11-13 cm). (5) Laminations swirl around the micronodules, seen in Core 24 , showing that they must have formed early in diagenesis, prior to significant compaction. (They are thus not concretions formed by upward diffusion later in diagenesis. Also, the micronodules contain virtually no included terrigenous material, suggesting that they grew on and not within the sediment.) (6) Passing from the organic-rich Hatteras Formation (Core 27) to the organic-poor lower unit of the Plantagenet Formation (Cores 27-24), there is little change in many metals (e.g., $\mathrm{Zn}, \mathrm{Cr}, \mathrm{Zn}, \mathrm{Sr}$ ), which only become much more enriched in the overlying Eocene, upper Plantagenet, and Bermuda Rise variegated claystones.

Arthur (1979) envisaged a large reservoir of reduced metallic ions in the anoxic pore waters of the Hatteras black shales, which was then mobilized upward during compaction. The color banding was formed as the different ions precipitated at different concentrations of dissolved oxygen near the sediment/water interface. It was believed these ions could also have contributed to the formation of zeolites. Other factors to be considered when evaluating Arthur's hypothesis are: (1) The manganese micronodules formed on the seafloor, yet much of the color banding and the formation of zeolites is diagenetic, so that upward exhalation would have had to persist for a very long period. (2) Minimal overburden in the Eocene probably meant that little compaction of the Hatteras black shales took place until gravity redeposition of the overlying Great Abaco Member in the Miocene. (3) Whereas some metals like $\mathrm{Mn}, \mathrm{Co}$, and $\mathrm{Ni}$ may be controlled by oxidation state, others also enriched are not (e.g., $\mathrm{Zn}$ ). In summary, the hypothesis of upward metal diffusion gains little support from the Site 534 data.

Instead it seems that slow accumulation over about $30 \mathrm{~m} . \mathrm{y}$. in strongly oxidizing bottom waters may have allowed all the metals to be incorporated from seawater and then locally redistributed during diagenesis to form the color banding and mottling.

\section{Paleoenvironmental Summary}

During the Late Cretaceous deposition of the lower Plantagenet unit took place below the calcite compensation depth at paleo-water depths of circa $5.5 \mathrm{~km}$ (Sheridan, Gradstein, et al., this volume). Evidence from other sites, summarized by Jansa et al. (1979), suggests that the calcite compensation depth rose to circa $4.5 \mathrm{~km}$ in the Eocene. Net accumulation rates were about $2.5 \mathrm{~m} /$ my from the Late Cretaceous to the late Eocene; dating is inadequate to resolve probable hiatuses.

Deposition and diagenetic models for the Late Cretaceous and late Eocene are illustrated in Figures 11 and 12. There were occasional influxes of terrigenous turbidites and calciturbidites from the continental margin, possibly related to lowered sea levels during the early Paleocene and early Eocene (Vail et al. 1977). Lowered sea levels could have tended to intensify bottom-water circulation (Fischer and Arthur, 1977), favoring nondeposition or even erosion. This fact may conceivably explain the absence of Paleocene sediments at Site 534 . During the later Eocene (and later Paleocene) when sea levels were high, bottom waters may have circulated more sluggishly, allowing more accumulation.

For at least a period of $30 \mathrm{~m}$.y., Pacific surface water probably flowed into the equatorial Atlantic, promoting 


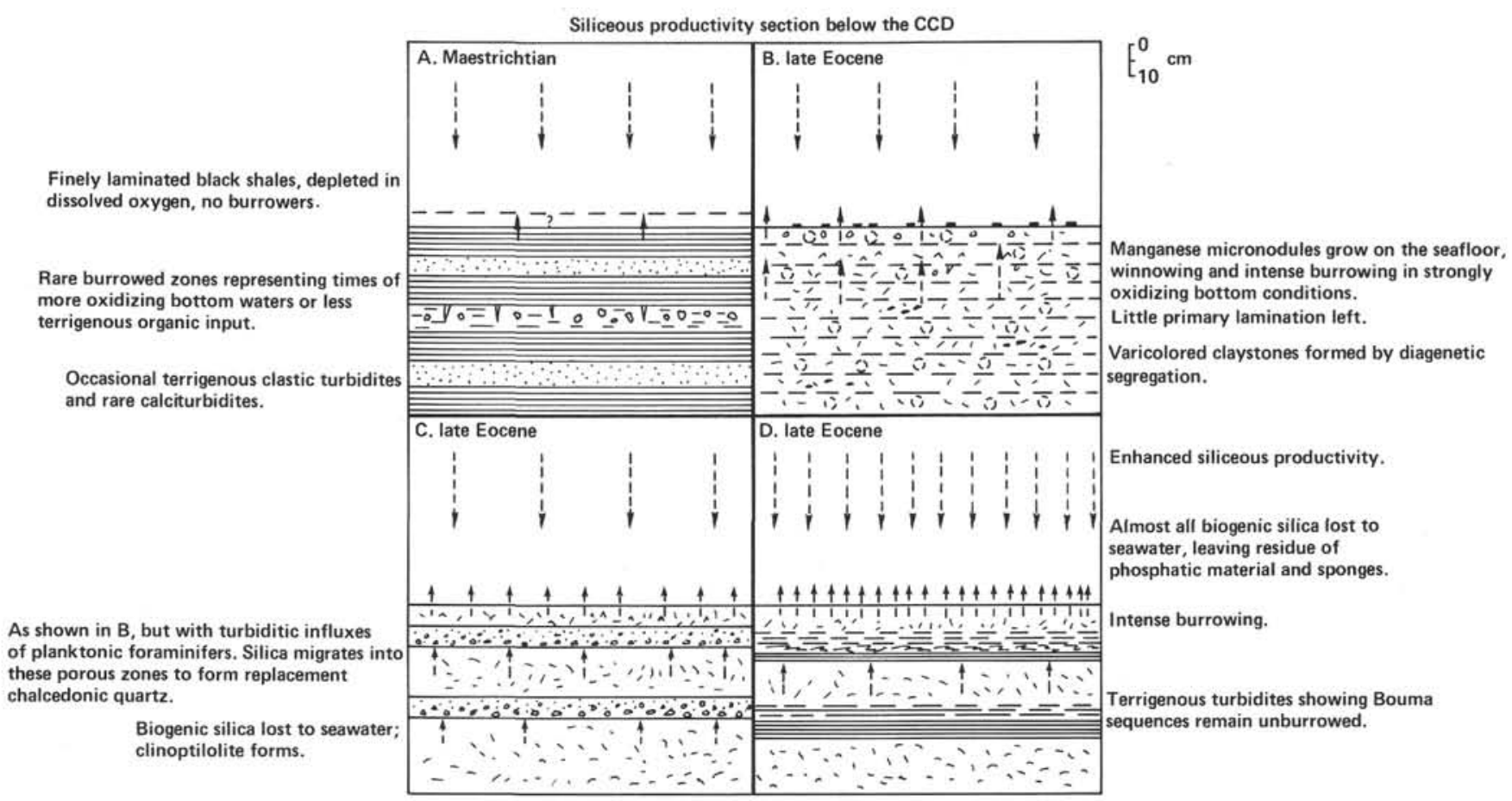

Figure 11. Sketches representing diagenetic processes during the Maestrichtian and late Eocene. A. Upper Cretaceous black shales of the Hatteras Formation. (High input of organic matter was coupled with weak bottom-water circulation. Sediments were depleted in dissolved oxygen; this depletion may have extended into the water column. There were occasional influxes of terrigenous and calcareous clastic sediments. Occasional paler burrowed intervals record either [or both] reduced input of organic matter or more oxidizing bottom waters.) B. By the Maestrichtian to the late Eocene, geostrophic currents were more active and the seafloor was oxidizing. (Sediments were highly burrowed, destroying most of the primary lamination. Manganese micronodules nucleated and grew on the seafloor, associated with metals. Diagenetic mobilization took place locally to form the varicolored appearance.) C. Superimposed on the regime shown in Figure 11 B. (Calciturbidites reached the area from the continental rise. Biogenic silica released from dissolution of diatoms and radiolarians diffused into the sediment, replacing foraminiferal shells, then precipitating in the porous zones between shells and in the shell chambers.) D. During the late Eocene, siliceous primary productivity was high, and terrigenous turbidites from the margin were more numerous. (Some of the turbidites preserved partial Bouma sequences, but otherwise the sediment was very highly burrowed. Radiolarians were not preserved, but the originally biogenous siliceous nature is shown by phosphatic material, more resistant sponge spicules, and relatively enriched levels of $\mathrm{Ba}$. Clinoptilolite formed diagenetically in these sediments.)

vigorous surface circulation and both equatorial and coastal upwelling. Rates of background terrigenous deposition were very low. Sediment was exposed on the seafloor to highly oxidizing corrosive bottom waters, with the result that, despite high surface productivity during this time, most of the biogenic silica dissolved at or near the sediment/water interface. Cherts formed preferentially where levels of dissolved silica were locally concentrated in porous calciturbidites.

Over about 30 m.y. the clays, silts, and muds were burrowed, oxidized and partly dissolved, producing a condensed metal-rich residuum. During sediment hiatuses, manganese micronodules formed on the sediment surface. Any Oligocene sediments were removed by erosion by geostrophic currents (up to $100 \mathrm{~m}$ ). Nondeposition or erosion was finally terminated in the early Miocene, when large volumes of carbonate were redeposited into the Blake-Bahama Basin, both from the Great Abaco Canyon and off the Blake Plateau and from the Bahamas further south (Bliefnick, Robertson, and Sheridan, this volume).

\section{CONCLUSIONS}

1. The uppermost Cretaceous (Maestrichian) and upper Eocene interval in the Blake-Bahama Basin, western
North Atlantic, consists of terrigenous siltstones, mudstones, siliceous and zeolitic claystones, minor micritic limestones, plus a small recovery of porcellanite and chert.

2. Comparisons of formations erected for the western North Atlantic (Jansa et al., 1979) show that at Site 534 four formations are represented: Hatteras (Maestrichtian), Plantagenet (Maestrichtian and upper Eocene), Bermuda Rise (upper middle and upper Eocene), and the base of the Blake Ridge Formation (upper Middle and upper Eocene). Microfossil ages allow recognition of a Tertiary Plantagenet unit. Thus the Plantagenet Formation is informally divided into the Cretaceous lower Plantagenet unit, cored at other sites, and an upper Eocene upper Plantagenet unit.

3. Redeposited terrigenous and carbonate material is interpreted as having been derived from the adjacent American continental margin. The predominant varicolored claystones, often zeolitic, are enriched in metals (e.g., $\mathrm{Fe}, \mathrm{Mn}, \mathrm{Cu}$ ) relative to normal hemipelagic muds and clays. Manganese micronodules formed on the sediment surface, particularly in the Late Cretaceous lower Plantagenet unit.

4. The metal enrichment can be explained by slow net sediment accumulation in highly oxidizing bottom 


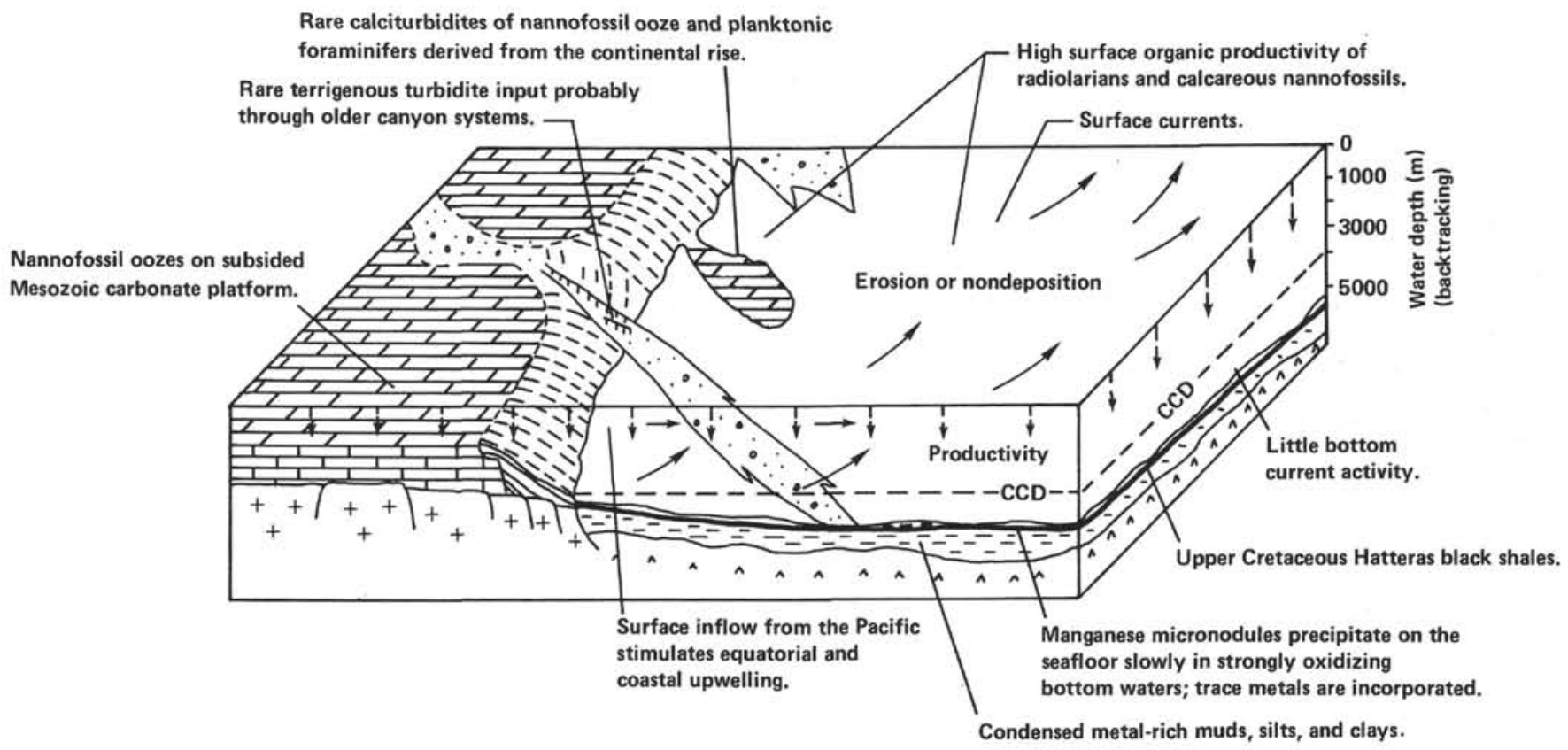

Figure 12. Depositional model for the late Eocene at the time of the Bermuda Rise Formation. (The model is not intended to be representative of the continental margin, which cannot be reconstructed in detail. By the Eocene, the Mesozoic carbonate platform of the Blake Plateau had subsided and was undergoing accumulation of nannofossil oozes. Submarine canyons persisted from the Mesozoic, allowing terrigenous turbidites to flow into the Blake-Bahama Basin. Nannofossil oozes and planktonic foraminiferal carbonates were also occasionally redeposited from the continental rise. There was high surface productivity, as nutrient-rich waters flowed in from the Pacific. Mixed siliceous terrigenous silt, mud, and clay accumulated on the seafloor below the carbonate compensation depth. Oxidizing geostrophic bottom currents kept sediment deposition to a minimum and may have caused some erosion. Metals, including manganese nodules, accumulated slowly from seawater to form highly condensed successions.)

waters during a 30-m.y. period of low detrital sediment input from the continental margin. Chemical analyses favor slow accumulation of the metals from seawater rather than hydrothermal input, or upward mobilization of metals from the underlying Upper Cretaceous Hatteras Formation.

5. Phosphatic material, including fish teeth and bones, plus relative $\mathrm{Ba}$ enrichment (not considered to be of hydrothermal origin), confirms high organic productivity during the late Eocene. This is related to inflow and upwelling of nutrient-rich waters from the Pacific. Much of the biogenic silica is believed to have been dissolved at or near the seafloor to produce a condensed residuum, despite the high surface productivity. Deposition below the calcite compensation depth also ensured that calcite was not preserved except for calciturbidites.

6. Virtually none of the chert was recovered, although it is probably abundant in both the Bermuda Rise Formation and the upper unit of the Plantagenet Formation (both Eocene). Although almost all the claystones are siliceous, some porcellanous, true cherts were found only where calciturbidites had been preferentially silicified. Porous sediments with little matrix (packstone fabric) were favored sites of dissolved silica migration and concentration to form porcellanite and chert.

7. The combination of terrigenous clay and biogenic silica was ideal for formation of abundant clinoptilolite later in diagenesis. No significant volcanic component was detected at Site 534 .

8. The absence of the Eocene Bermuda Rise and Plantagenet formations at Site $391,2 \hat{z} \mathrm{~km}$ to the north- west, had implied extensive erosion throughout the Blake-Bahama Basin at this time. However, the presence of these formations at Site 534 shows that erosion was much less deep and extensive. Seafloor erosion of up to $100 \mathrm{~m}$ of sediment by geostrophic bottom current could still explain the general absence of Oligocene sediments from the Blake-Bahama Basin. Minor erosional hiatuses in the Maestrichtian to Eocene interval (e.g., the Paleocene) may possibly be a function of sea-level fluctuations.

\section{ACKNOWLEDGMENTS}

Helpful discussion with shipboard colleagues and Dr. N. B. Price (Edinburgh) are acknowledged. For assistance with laboratory work, I am grateful to J. Godall (scanning electron microscope), Mrs. D. James (X-ray fluorescence), and Mrs. D. Baty (photography). The manuscript was reviewed by L. F. Jansa, H. C. Jenkyns, and J. Ogg.

\section{REFERENCES}

Arthur, M. A., 1979. Origin of Upper Cretaceous multicolored claystones of the western Atlantic. In Tucholke, B. E., Vogt, P. R., et al., Init. Repts. DSDP, 43: Washington (U.S. Govt. Printing Office), 417-420.

Arthur, M. A., and Natland, J. H., 1979. Carbonaceous sediments in the North and South Atlantic: the role of salinity in stable stratification of Earth Cretaceous basins. In Talwani, M., Hay, W., and Ryan, W. B. F. (Eds.), Deep Drilling Results in the Atlantic Ocean: Continental Margins and Paleoenvironment. Am. Geophys. Union, Maurice Ewing Series, 3:375-401.

Benson, W. E., Sheridan, R. A., et al., 1978. Init. Repts. DSDP, 44: Washington (U.S. Govt. Printing Office).

Boström, K., Joensuu, O., Moore, C., Boström, B., Dalziel, M., and Horowitz, A., 1973. Geochemistry of Barium in pelagic sediments. Lithos, 6:159-174 


\section{A. H. F. ROBERTSON}

Chamley, H., 1979. North Atlantic clay sedimentation and paleoenvironment since the late Jurassic. In Talwani, M., Hay, W., and Ryan, W. B. F. (Eds.), Deep Drilling Results in the Atlantic Ocean: Continental Margins and Paleoenvironment. Am. Geophys. Union, Maurice Ewing Series, 3:324-361.

Dow, W. G., 1978. Geochemical analysis of samples from 391A and 391C, Leg 44, Blake-Bahama Basin. In Benson, W. E., Sheridan, R. E., et al. Init. Repts. DSDP, 44: Washington (U.S. Govt. Printing Office), 625-635.

Fischer, A. G., and Arthur, M. A., 1977. Secular variations in the pelagic realm. In Cook, H. E., and Enos, P. (Eds.), Deep Water Carbonate Environments. Soc. Econ. Paleont. Mineral. Spec. Publ., 25:19-50.

Jansa, L. F., Enos, P., Tucholke, B. E., Gradstein, F. M., Sheridan, R. E., 1979. Mesozoic-Cenozoic sedimentary formations of the North American Basin; Western North Atlantic. In Talwani, M., Hay, W., Ryan, W. B. F. (Eds.), Deep Drilling Results in the Atlantic Ocean: Continental Margins and Paleoenvironment. Am. Geophys. Union, Maurice Ewing Series, 3:1-58.

Kastner, M., 1979. Zeolites. Mineral. Soc. Am. Short Course Notes, 6:111-120.

Lancelot, Y., Hathaway, J. C., and Hollister, C. D., 1972. Lithology of sediments from the western North Atlantic, Leg 11, Deep Sea Drilling Project. In Hollister, C. D., Ewing, J. I., et al., Init. Repts. DSDP, 11: Washington (U.S. Govt. Printing Office), 901-950.

Murdmaa, I. O., Gordeev, V. V., Bazilevskaya, E. S., and Emelyanov, E. M., 1978. Inorganic geochemistry of the Leg 44 sediments. In Benson, W. E., Sheridan, R. E., et al., Init. Repts. DSDP, 44: Washington (U.S. Govt. Printing Office), 463-476.

Norrish, K., and Hutton, J. T., 1969. An accurate X-ray spectrographic method for the analysis of a wide range of geological samples. Geochim. Cosmochim. Acta, 33:431-454.
Ramsay, A. T. S., 1973. A history of organic siliceous sediments in the oceans. In Hughes, N. F. (Ed.), Special Papers in Palaeonto$\log y$ (Vol. 12): London (Palaeontol. Assoc.), 199-234.

Riech, V., 1979. Diagenesis of silica, zeolites, and phyllosilicates at Sites 397 and 398. In von Rad, U., and Ryan, W. B. F., et al., Init. Repts. 47, Pt. 1: Washington (U.S. Govt. Printing Office), 741-759.

Riech, V., and von Rad, U., 1979. Silica diagenesis in the Atlantic ocean: diagenetic potential and transformations. In Talwani, M., Hay, W., and Ryan, W. B. F. (Eds.), Deep Drilling Results in the Atlantic Ocean: Continental Margins and Paleoenvironment. Am. Geophys. Union, Maurice Ewing Series, 3:315-340.

Robertson, A. H. F., 1978. The origin and diagenesis of cherts from Cyprus. Sedimentology, 24:11-30.

Sheridan, R. E., Enos, P. Gradstein, F. M., and Benson, W. E., 1978. Mesozoic and Cenozoic sedimentary environments in the western North Atlantic Ocean. In Benson, W. E., Sheridan, R. E., et al., Init. Repts. DSDP, 44: Washington (U.S. Govt. Printing Office), 971-980.

Turekian, K. K., and Wedepohl, K. H., 1961. Distribution of elements in some major units of the earth's crust. Geol. Soc. Am. Bull., 72: 175-192.

Vail, P. R., Mitchum, R. M., Jr., and Thompson, S., III, 1977. Global cycles of relative changes in sea level. Am. Assoc. Pet. Geol. Mem., 26:83-97.

von Rad, U., and Rösch, H., 1972. Mineralogy and origin of clay minerals, silica and authigenic silicates in Leg 14 sediments. In Hayes, D. E., Pimm, A. C., et al., Init. Repts. DSDP, 14: Washington (U.S. Govt. Printing Office), 727-752.

Date of Initial Receipt: July 12, 1982 